\title{
Functional traits of the invasive species Thunbergia alata (Acanthaceae) and its importance in the adaptation to Andean forests
}

\section{Rasgos funcionales de la especie invasora Thunbergia alata (Acanthaceae) y su importancia en la adaptación a bosques andinos} Acta Botanica Mexicana

\author{
Mario Alberto Quijano-Abril’,2,5 (D), María de los Ángeles Castaño-López,2 (D), Daniela Marín-Henaol (D), David Sánchez- \\ Gómezl iD, José Miguel Rojas-Villa1,3 (iD, Jorge Sierra-Escobar1,2,4 (D)
}

\begin{abstract}
:
Background and Aims: Thunbergia alata is one of the ten most problematic invasive plant species in Colombia. Its rapid colonization and adaptation to Andean forests have affected the composition and structure of indigenous plant communities. In this research, analysis of functional traits was carried out, generating new information that could explain the rapid colonization, adaptation and invasive potential of $T$. alata in this type of Andean environment.

Methods: To obtain this information, a series of observations were made on the morphology and anatomy of roots, stems, leaves, flowers, fruits and seeds. Likewise, a characterization of its floral visitors and symbiotic relationships with soil microorganisms was carried out.

Key results: We determined that both morphological traits and interaction phenomena favour the adaptability of T. alata in Andean forests and could contribute to a greater extent to its active colonization in this type of environment. An active association of $T$. alata was found with different species of native and introduced floral visitors, with a total of 2266 floral visits made during our study by seven species of insects belonging to the orders Coleoptera and Hymenoptera. Mycorrhizal fungal spores associated with T. alata populations were found at all sampling sites. The number of spores per $100 \mathrm{~g}$ of soil varied between 300 and 424. All the roots of T. alata, without exception, had high colonization by arbuscular mycorrhizal fungi.

Conclusions: We believe that the information obtained in this research will contribute to the generation of comprehensive and effective strategies for the control of this species in Andean forests.
\end{abstract}

Key words: Colombia, invasive plants, functional traits, loss of biodiversity.

\section{Resumen:}

Antecedentes y Objetivos: Thunbergia alata es una de las diez especies de plantas invasoras más problemáticas de Colombia. Su rápida colonización y adaptación a los bosques andinos ha afectado la composición y estructura de las comunidades vegetales nativas. En esta investigación se realizó un análisis de rasgos funcionales, generando nueva información que podría explicar la rápida colonización, adaptación y potencial invasor de $T$. alata en este tipo de ambientes andinos.

Métodos: Para obtener esta información se realizó una serie de observaciones sobre la morfología y anatomía de raíces, tallos, hojas, flores, frutos y semillas. Asimismo, se realizó una caracterización de sus visitantes florales y de las relaciones simbióticas con los microorganismos del suelo.

Resultados clave: Se determinó que tanto los rasgos morfológicos como los fenómenos de interacción favorecen la adaptabilidad de T. alata en los bosques andinos y podrían contribuir en mayor medida a su colonización activa en este tipo de ambientes. Se encontró una asociación activa de $T$. alata con diferentes especies de visitantes florales nativos e introducidos, con un total de 2266 visitas florales realizadas durante nuestro estudio por siete especies de insectos pertenecientes a los órdenes Coleoptera e Hymenoptera. En todos los sitios de muestreo se encontraron esporas de hongos micorrizógenos asociadas a las poblaciones de T. alata. El número de esporas por $100 \mathrm{~g}$ de suelo variaba entre 300 y 424 . Todas las raíces de T. alata, sin excepción, presentaban una alta colonización por hongos micorrizógenos arbusculares.

Conclusiones: Creemos que la información obtenida en esta investigación contribuirá a la generación de estrategias integrales y efectivas para el control de esta especie en los bosques andinos.

Palabras clave: Colombia, pérdida de biodiversidad, plantas invasoras, rasgos funcionales.

${ }^{1}$ Grupo de Investigación Estudios Florísticos, Facultad de Ingeniería, Universidad Católica de Oriente, apartado aéreo 008, Rionegro, Colombia.

${ }^{2}$ Facultad de Ingeniería, Universidad Católica de Oriente, apartado aéreo 008, Rionegro, Colombia.

${ }^{3}$ Facultad de Ciencias Agropecuarias, Universidad Católica de Oriente, apartado aéreo 008, Rionegro, Colombia.

${ }^{4}$ Laboratorio de suelos, Facultad de Ingeniería, Universidad Católica de Oriente, apartado aéreo 008, Rionegro, Colombia.

${ }^{5}$ Author for correspondence: maquijano@uco.edu.co
Received: March 15, 2021

Reviewed: May 9, 2021.

Accepted by Moisés Méndez Toribio: September 15,

2021.

Published Online first: October 19, 2021

Published: Acta Botanica Mexicana 128 (2021).
To cite as: Quijano-Abril, M. A., M. A. Castaño-López, D. Marín-Henao, D. Sánchez-Gómez, J. M. Rojas-Villa and J. Sierra-Escobar. 2021. Functional traits of the invasive species Thunbergia alata (Acanthaceae) and its importance in the adaptation to Andean forests. Acta Botanica Mexicana 128: e1870. DOI: https://doi. org/10.21829/abm128.2021.1870 


\section{Introduction}

Biological invasions of plants are becoming more frequent worldwide and are considered one of the main causes of the loss of biodiversity (Jaramillo, 2017). The effects of plant invasions cause an alteration of the processes that occur within ecosystems, affecting the composition and structure of native plant communities. This occurs mainly due to the fragmentation of the forests leading to the emergence of new foci of invasion (Baptiste et al., 2010).

Invasive plant species are organisms that have a superior capacity to adapt to new environmental conditions that, unlike other plants, allows them to establish a wide range of distribution and establishment in foreign habitats (Sakai et al., 2001). These species promote the loss of biological diversity, generate competition, and alter the spaces for native plants (Ruiz et al., 2018). Most invasive species have a high reproductive rate and a wide range of adaptation, thus determining their success in various environments (Ríos and Vargas, 2003). Currently, few papers analyse the traits that allow the rapid colonization and efficient adaptation of these species. This knowledge is a fundamental aspect for adequate control of invasive plants (LópezGarcía et al., 2011; Cárdenas-López et al., 2017; OcampoZuleta and Solorza-Bejarano, 2017).

Various authors have developed research to generate lists of plant species that are altering ecosystems and their biological characteristics (D'Antonio et al., 2004; Baptiste et al., 2010; Arslan et al., 2015; García-Duque et al., 2016; Campoy et al., 2018), but there are still many gaps in the management of such plant species. Given the lack of clarity on the issue, a knowledge of morphology, physiology, and life history of any invasive species should be established as a priority to implement effective control guidelines (Mack et al., 2000; Pérez-Bedmar and Sanz-Pérez, 2003; Gutiérrez, 2006).

The Andean forests have been classified as strategic ecosystems in Colombia because of the strong pressure caused by urban expansion and because these forests are habitat for a great diversity of flora and fauna, both endemic and threatened species (Van der Hammen and Cleef, 1983; Alzate et al., 2008; González-Orozco, 2021). A large part of the country's human population is located in this type of environment and has modified a large part of its natural cover, favouring the colonization of exotic species and causing considerable damage (Armenteras et al., 2003; Gómez et al., 2007; Raczka et al., 2019). One of the ten most problematic invasive plant species in the country is Thunbergia alata Bojer ex Sims (García-Duque et al., 2016). Its rapid colonization and adaptation to Andean forests have encouraged different initiatives that seek its control and management. However, many of these attempts have not been efficient since different aspects of its life history and morphological traits are unknown.

Thunbergia alata is a twining perennial herb of the family Acanthaceae with sagittate leaves and axillary orange flowers. This species was described in 1825 by the physician and taxonomist John Sims and the Czech naturalist Wenceslas Bojer, from seeds grown from a specimen from Mauritius, East Africa. In the original publication, the authors highlight the aesthetic value of the species and affirm that it was initially planted under greenhouse conditions in February and flowered four months later in June of the same year, a phenomenon very different from that found in our Andean forests where it starts flowering four weeks after germination (Sims, 1801).

In later years this species was taken to the European colonies in the Antilles, where it rapidly dispersed, followed by its naturalization (Meyer and Lavergne, 2004). In America particularly it was introduced in the nineteenth century for ornamental purposes, thus beginning its dispersion especially by gardening enthusiasts (Meyer and Lavergne, 2004). Currently the species is considered a highly invasive plant, mainly in tropical and subtropical areas around the world (Olden and Poff, 2003; Lockwood et al., 2005).

For Colombia the exact period of its introduction has not yet been recorded, however, the medical doctor and geographer Manuel Uribe Ángel gives some information about its appearance in the Antioquia region, since he left a record of it in his "Geografía General y Compendio Histórico del Estado de Antioquia en Colombia" (Uribe-Ángel, 1885). By 1885 , T. alata was already described as a common species in the montane forests of the department of Antioquia (Uribe-Ángel, 1885). According to the records of the Colombian National Herbarium (COL), the first Colombian individual of $T$. alata present in this herbarium, corresponds to a specimen collected in 1939 by Enrique Pérez Arbeláez and 
José Cuatrecasas around La Vega, Cundinamarca (Baptiste et al., 2010), and in the case of Antioquia there is a 1940 record by Lorenzo Uribe Uribe. The recorded dates have yielded enough information to suggest some notions about the displacement and successful dispersal of the species throughout America generally and Colombia specifically. However, there is still insufficient information to accurately determine the plant's appearance in the montane forests of Colombia.

In this research we carried out an analysis of some of the functional traits that could explain the rapid colonization and adaptation of Thunbergia alata to Colombian ecosystems such as montane forest. There are not many studies that deal in detail with these types of characters and their role with an invasive species. For this reason, our results may be an important tool in future research on the dynamics and ecology of this invasive species in Andean forests.

\section{Materials and Methods}

\section{Study area}

This study was carried out in the Cordillera Central of the Andes, in the southeast of the department of Antioquia, Colombia, where four localities (Table 1 ) belonging to the lower montane rain forest life zone were sampled (Holdridge, 1967). All the localities were covered by secondary forest and scrub, the result of moderate anthropic alterations. All the sampling points evaluated showed a high degree of invasion of T. alata (Fig. 1). The approximate elevation of the samples was $2150 \mathrm{~m}$ a.s.l., and the temperature varied between 13 and $22{ }^{\circ} \mathrm{C}$ with a mean annual rainfall of $2272 \mathrm{~mm}$ (IDEAM, 2005). The coordinate system used was Magna_Colombia_Bogota (IGAC, 2021).

\section{Anatomical characters}

To carry out the anatomical analyses, stems and roots were collected in different stages of development, as well as leaves, fruits, and seeds. These were fixed in FAA (formaldehyde, alcohol, and acetic acid) for 48 hours at $4{ }^{\circ} \mathrm{C}$. They were dehydrated in a series of ethanol $(50 \%, 60 \%, 70 \%, 80 \%, 90 \%$, and $95 \%)$. The stems and seeds were softened in a solution composed of ethanol and glycerine six: (i) for 96 hours at $4{ }^{\circ} \mathrm{C}$ before dehydration. After completion of dehydration, all structures were immersed in HistoChoice ${ }^{\circledR}$ for 24 hours. Subsequently, they were infiltrated in a transient solution composed of HistoChoice ${ }^{\circledR}$ and (ii): one Paraplast ${ }^{\circledR}$ paraffin. Finally, they were embedded in three series of Paraplast ${ }^{\circledast}$ paraffin for 12 hours at $60^{\circ} \mathrm{C}$. Anatomical sections cut were 5-7 $\mu \mathrm{m}$ thick, using a Leica RM2125 rotary microtome (Leica, Wetzlar, Germany). Two stains were used: Toluidine Blue $0.5 \%$ and Safranin plus Alcian Blue one.

For the stems, the arrangement and composition of vascular tissues were analysed, as well as the "Lianescent Vascularization Syndrome" (Carlquist, 1985a; Ewers et al., 1992; Angyalossy et al., 2015). Anatomical descriptions of the mesophyll and epidermis were made from leaves. For the roots the types of epidermis, cortex, endodermis, and vascular bundles were evaluated. Finally, by means of longitudinal sections of the seeds, the exotesta, mesotesta and endotesta were examined. Similarly, the morphology of the embryo, its position within the seed, and its degree of development were described. The terminology used to describe the anatomical features was taken from Martin (1946), Carlquist and Zona (1988), Balkwill and Campbell-Young (1999). Anatomical characters are useful for understanding the physiological processes in the plant during its growth. The anatomical composition of roots, stems and leaves allow to find ecological patterns related with vascular system water conduction capacity, due to the pivotal role that the xylem tissue plays in the plant's adaptation to different environments (Carlquist, 1985a; Wahl and Ryser, 2000; Angyalossy et al., 2015). Furthermore, coat and seed

Table 1: Sampling locations, Antioquia, Colombia.

\begin{tabular}{cccllr}
\hline Locality & $\mathrm{x}$ & \multicolumn{1}{c}{$\mathrm{y}$} & \multicolumn{1}{c}{ Locality } & Municipality & Elevation $\mathrm{m}$ a.s.I. \\
\hline 1 & 848934,459 & 1159573,699 & Vereda La Milagrosa & La Ceja & 2125 \\
2 & 857454,005 & 1172058,593 & Barrio Santa Ana & Rionegro & 2200 \\
3 & 861222,891 & 1166180,966 & Vereda La Palma & El Carmen de Viboral & 2150 \\
4 & 862345,968 & 1173030,232 & Vereda El Chagualo & Marinilla & 2120 \\
\hline
\end{tabular}




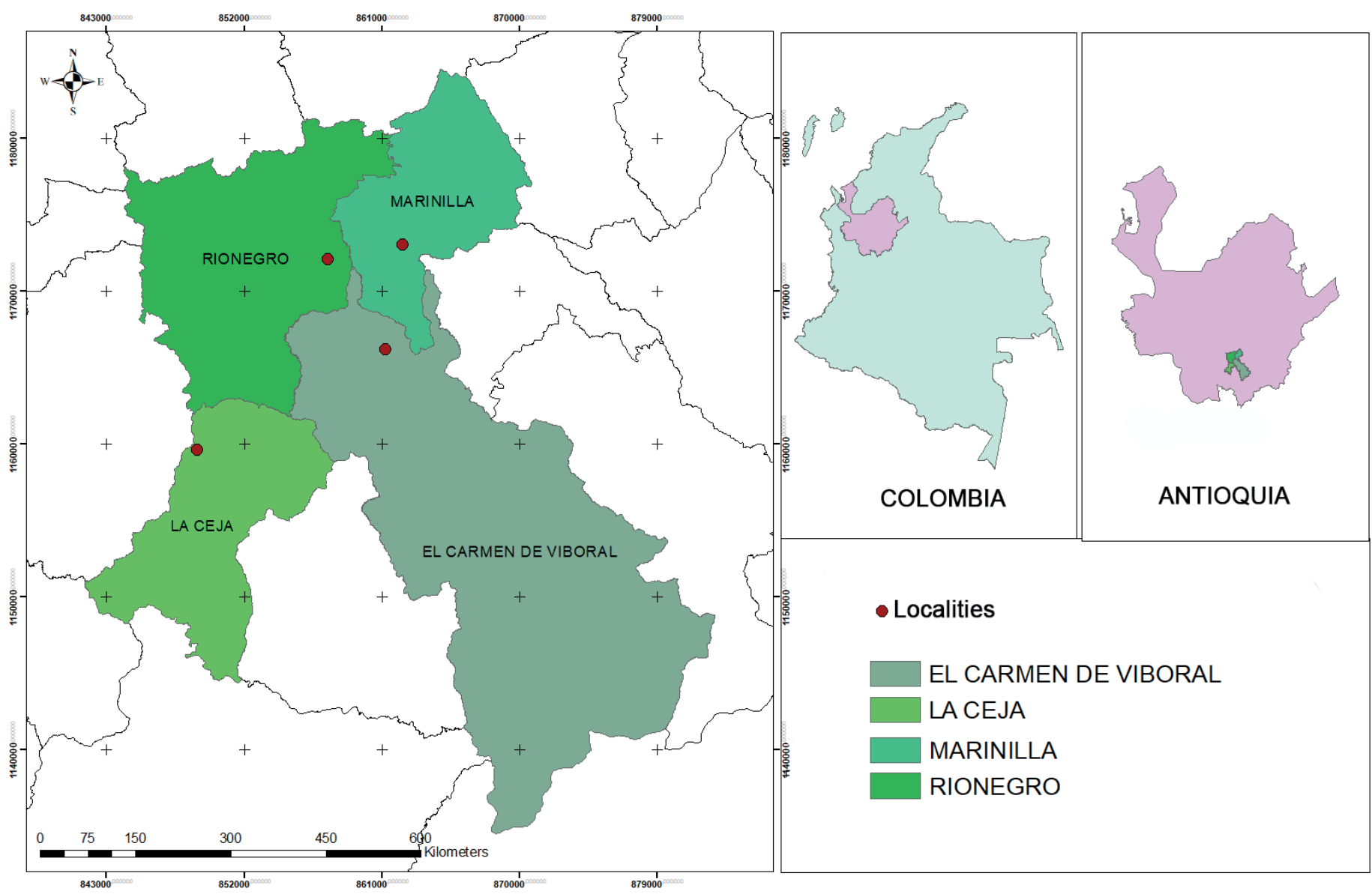

Figure 1: Location map of the sampling sites of Thunbergia alata Bojer ex Sims in Antioquia, Colombia.

anatomy are essential to understandinging the seed dormancy, a character considered one of the most important in the ecosystems regenerative processes (Baskin and Baskin, 2014). These germination and dormancy traits lead to a germination timing that not only bridges unfavourable conditions, but also optimizes the fitness of seedlings by delivering germinated seeds at the best moment (Saatkamp et al., 2019).

\section{Floral morphology and pollen characters}

The description and data collection of the floral morphology was base on 50 flowers, 25 were collected in locality two and 25 in locality three (Table 1). The flowers were collected directly from the plant with the help of pruning shears. Characters such as color, symmetry, floral arrangement, presence and location of the nectar, number and degree of fusion of the petals, position and morphology of the stamens, as well as the shape of the stigma, were evaluated (Simpson, 2019; Manktelow, 2000; Hegland and Totland, 2005).

For the observation and mounting of the pollen grains, a collection of 50 flower buds was used. From these, the stamens were extracted and were macerated and sieved with a pore size of $150 \mu \mathrm{m}$, to obtain the pollen grains. The pollen grains were processed by applying Erdtman's acetolysis (Erdtman, 1969). For the assembly of permanent plates, a piece of glycerinated gelatine was used. It was impregnated with a little of the processed sample and was placed on a slide and sealed with paraffin. The evaluated characters were the type of opening, ornamentation, and shape of the pollen grain. Measurements were taken to determine the size of the pollen grain and the thickness of the exine. The terminology used for the description of the pollen grain was based on Halbritter et al. (2018). 
Germination time for the pollen grain was also determined. For this, the grains were exposed to different concentrations of sucrose ( $2 \%, 2.5 \%, 4.5 \%$, and $5 \%)$, (García et al., 2015), taking a sample of each of the concentrations every five minutes for 25 minutes and observing it in a Leica DM500 optical microscope with a magnification of $10 \times$ (Leica, Wetzlar, Germany). Data were taken from the germination period of the pollen grain and the number of pollen grains per minute was analysed for one pollen tube. The emergence point of the pollen tube was determined.

\section{Floral visitors}

For the sampling of floral visitors, the methodology proposed by Vaissière et al. (2011) was used, where five quadrants were determined in each chosen locality with an area of $1 \mathrm{~m}^{2}$, for a total of 20 sampling units. A count was made of the $T$. alata flowers in the quadrant and subsequently, observations of 15 minutes were made every hour for three hours a day for five weeks. During the observations, data such as visit time and number of flowers visited were recorded. Also, a collection was made of the flower visitors who were in the quadrant. The insect samples were deposited in the entomological collection of the Universidad Católica de Oriente (UCO), the samplings were carried out in the months of August and September 2019.

\section{Fruit morphology and dehiscence}

A collection of about 150 fruits of T. alata in different stages of maturation was made. The fruits were collected in the four previously mentioned locations. The number of fruits collected in each of the localities varied depending on the phenology of the individuals of the populations. Thirty fruits corresponded to localities one and two, and 40 and 50 to localities three and four, respectively (Table 1). We described them and evaluated the characters such as the maturation period, length, type of dispersal, and the number of seeds contained in each of them.

\section{Soil seed bank}

Within the four studied localities, we gathered soil seedling samples from three plots of $1 \mathrm{~m}^{2}$ that had a seedling bank of which $0.2 \mathrm{~m}^{3}$ of soil was extracted and sieved to extract the seeds, and a respective count was made. Of the total number of seeds found in each plot, 150 were taken and these were sown in Petri dishes in three groups of 50 seeds each. We evaluated germination percentage and the Median Length of Germination time (MLG) from these.

The physical condition of the testa was compared from some seeds sampled from the soil seed bank and these were compared with those extracted directly from the ripe fruits. The analysis was done with the help of a ZEISS Stemi305 stereoscope (Jena, Germany). We determined qualitative and quantitative traits such as the presence, colour and texture of the testa, the diameter of the seed and the length of the ventral and dorsal area.

\section{Germination percentages}

Mature fruits were collected, and seeds were extracted. The seeds were cleaned with hypochlorite and sown in rectangular trays of $10 \times 25 \times 50 \mathrm{~cm}$ with 50 cavities using peat as substrate. Irrigation was periodically applied manually. A maximum of 50 seeds was sown in the germination trays. Each tray was prepared and marked with a code, individual number, and sowing date.

To estimate the influence of light intensity on germination, four treatments were carried out, varying the light intensity by means of a woven mesh composed of polyethylene fiber. Treatment one (T1) was subjected to $100 \%$ light, treatment two (T2) had 50\% light, treatment three (T3) was subjected to a light intensity of $25 \%$, and treatment four (T4) was performed with a light intensity of $5 \%$. Germination was monitored every day for four weeks and variables such as the Median Length of Germination time days $(M L G)$ and the germination percentage were evaluated for each treatment.

\section{Seedling functional morphology}

Functional traits of the seedlings were measured as follows: position, emergence, and function of the cotyledons in order to classify them according to the functional groups proposed by Garwood (1996). In addition, other specific morphological characters of hypocotyl, cotyledons, epicotyl, and leaves were observed to determine the variation in shape and size of the seedlings. These traits were determined from the biological material of the germination tests. Each seedling was evaluated according to some de- 
velopmental stages that were identified considering the total expansion of some structures. For the morphological description in each phase, ten specimens were extracted. Finally, descriptions of the seedlings were made based on characters reported by Garwood et al. (2009). These characters were observed with the aid of a ZEISS Stemi305 stereoscope (Jena, Germany). A photographic record of the seedling was made for each stage, and photographs were taken of particular structures, such as cotyledons, epicotyl and the first leaves that are also useful for identification in the field. The pictures were taken with a Canon EOS 4000D camera (Ōta, Tokio).

\section{Mycorrhizal symbiosis}

To determine mycorrhizal colonization in T. alata, spore counts and root staining were performed. For this, root and soil samples of T. alata were collected in the four selected localities. At least five roots were collected from different individuals and five soil samples per site. The roots were extracted from adult or juvenile plants. To avoid confusion with other soil roots, only fine roots that were attached to the main root of the plant were processed. Likewise, a subsample (approximately $100 \mathrm{~g}$ ) of soil was taken per collected root, preferably from the rhizoplane, which is the part of the root that is in contact with the soil and is where the greatest number of microorganisms are found.

The spore count was carried out on the field soil samples. This consisted of taking a subsample of $20 \mathrm{~g}$ of soil that was placed in a $500 \mathrm{ml}$ beaker with $300 \mathrm{ml}$ of water and 0.15 $\mathrm{g}$ of sodium pyrophosphate. This was stirred for 15 minutes, and the supernatant was transferred into a battery of sieves (250, 106 and $53 \mu \mathrm{m})$ that was centrifuged with a $70 \%$ sugar solution for 5 minutes with a Arlesa Digicen 2116500 RPM centrifuge (Arlesa, Madrid, Spain). The content of each tube was poured into its respective sieve and washed with running water. Subsequently, the sediment product of this centrifugation was collected on filter paper for reading (Habte and Osorio, 2001). Finally, the spore count was performed with a ZEISS Stemi305 stereoscope (Jena, Germany).

The mycorrhizal colonization of the roots obtained in the field was determined by the intercept method (Giovannetti and Mosse, 1980) from the number of positive fields (presence of arbuscules, vesicles and hyphae) inside the root.
For this, the finest roots were rinsed with $10 \% \mathrm{KOH}$ (Phillips and Hayman, 1970) and then stained with $0.15 \%$ acid fuchsin in lactic acid (Kormanik et al., 1980). The stained roots were then placed in a checkered Petri dish for observation with a ZEISS Stemi305 stereoscope (ZEISS, Jena, Germany). The data were subjected to Duncan's multiple range test and Fisher's LSD test, for which a significance level of $P \leq 0.05$ was used. All analyses were conducted in the R software environment (R Core Team, 2019).

\section{Results}

\section{Anatomical description of the plant body}

Cross sections of the roots of $T$. alata revealed anatomical characteristics such as uniseriate epidermis with horizontally elongated cells, followed by the exodermis with thin-walled cuboid cells. The cortex consisted of nine to ten layers of parenchymal cells with interruptions caused by the mycelial formation of mycorrhizal fungi. Endodermis with sinuosities was observed in the pericline wall of the cells as well as alternate radial vascular bundles made up of vasicentric tracheids adjacent to libriform sclerenchyma fibers and interaxillary phloem (Fig. 2A).

The anatomy of the stem allowed us to observe the "Lanescent Vascularization Syndrome", consisting of vessels of varying sizes arranged radially around the hollow medulla and vasicentric-type tracheids associated with adjacent thick-walled libriform sclerenchyma fibers (Figs. 2B, C) and interaxillary phloem contiguous to thin-walled apotracheal axial parenchyma. The successive vascular cambium with cork with seven to eight layers of cells had a phellodermis with three to four layers of cells and an uniseriate epidermis with cuboid cells (Fig. 2C). In contrast, the branches exhibited a larger hollow medulla compared to the stems including a uniseriate epidermis composed of semicircular to ellipsoidal cells with a thick lignified wall (Figs. 2D, E).

The leaves were characterized by the presence of an adaxial epidermis composed of horizontally aligned cuboid cells with a thickened periclinal wall and anticline wall with sinuosities (Figs. 2G, H). At the level of the midrib, a subepidermis formed by three to four layers of angular collenchyma cells was observed, followed by photosynthetic spongy parenchyma. Adjacent to this, it was possible to observe two to three layers of fundamental parenchyma cells enclosing 

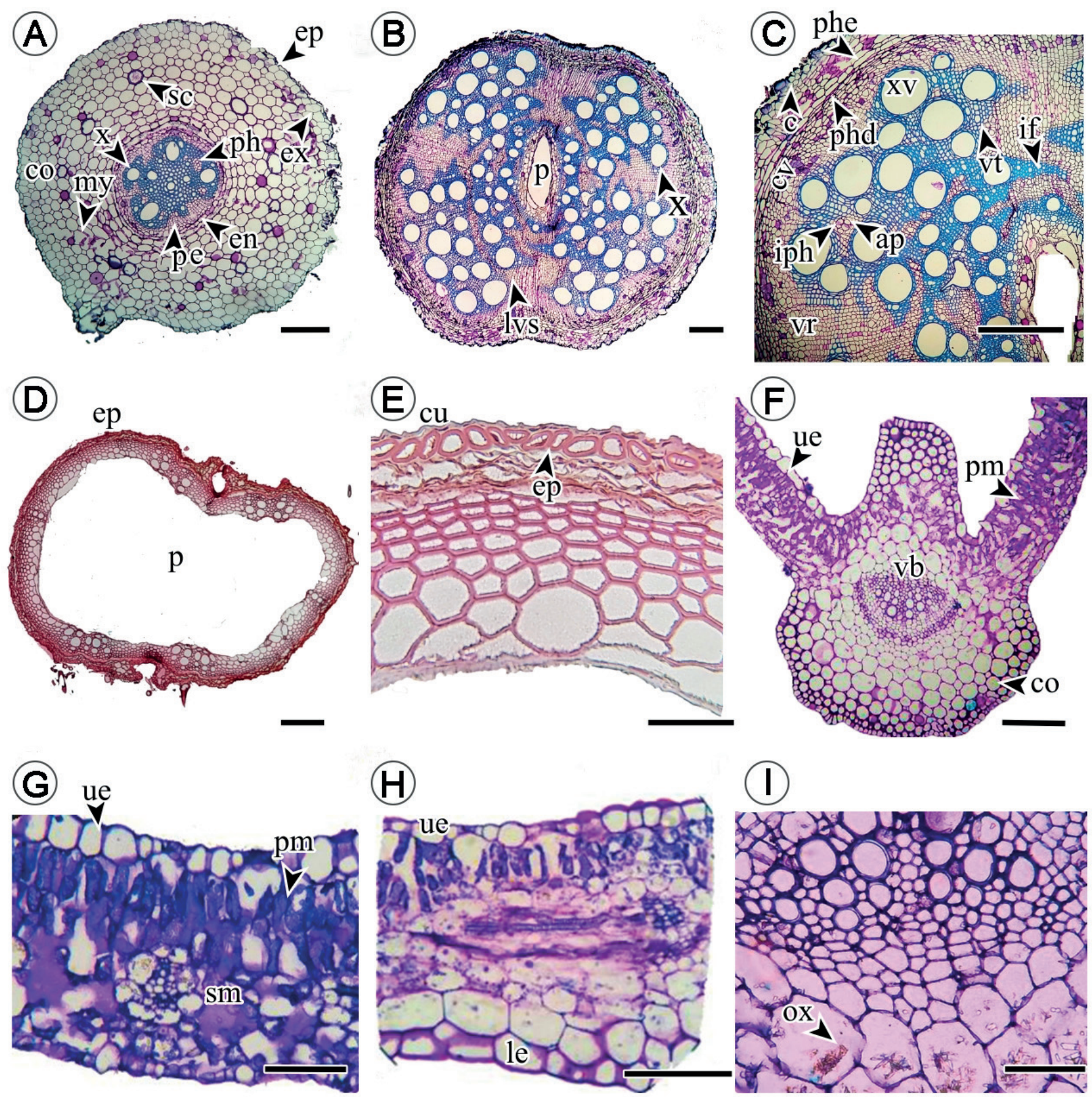

Figure 2: Cross section of Thunbergia alata Bojer ex Sims root, stems and leaves. A. root, ep $=$ epidermis, $c 0=c o r t e x, e x=e x o d e r m i s, m y=m y c e l i a, x=$ xylem, pe=pericycle, en = endodermis, ph = phloem; B-C. stems, Ivs = lianescent vascularization syndrome, $p=p i t h, x=x y l e m, a p=a x i a l ~ p a r e n c h y m a$, $\mathrm{c}=$ cork, $\mathrm{cv}=$ vascular cambium, iph = interaxillary phloem, if = libriform fibers, phd = phelloderm, phe = phellogen, $\mathrm{vr}=\mathrm{vascular}$ rays, $\mathrm{vt}=$ vasicentric tracheids, $x v=$ xylem vessels; D-E. branches, ep = epidermis, cu = cuticle, $p=$ pith; F, G, H, I. leaves, co = collenchyma, le = lower epidermis (abaxial), $\mathrm{ox}=$ calcium oxalate crystals, $\mathrm{pm}=$ palisade mesophyll, $\mathrm{sm}=$ spongy mesophyll, ue = superior epidermis (adaxial), vb = vascular bundle. Scale bar: $\mathrm{A}$ $=300 \mu \mathrm{m}, \mathrm{B}, \mathrm{D}=100 \mu \mathrm{m}, \mathrm{C}, \mathrm{E}=500, \mathrm{~F}=100 \mu \mathrm{m}, \mathrm{G}-\mathrm{H}=500 \mu \mathrm{m}$.

the vascular bundle with calcium oxalate contents in the form of drusen and raphidia (Figs. 2F, I). Dorsiventral mesophyll composed of one to two layers of palisade parenchyma cells and five to six layers of spongy photosynthetic paren- chyma with almost juxtaposed cells surrounded the vascular tissue (Fig. 2G). On the abaxial surface of the epidermis, the collenchyma consisted of two to three cell layers, while the fundamental parenchyma was six-seven cell layers (Fig. 2F). 
The seeds were albuminous, unitegmic (a single integument), with an exotesta composed of three-four layers of longitudinally elongated palisade cells arranged in the form of discontinuous projections (Figs. 3A-C). The mesotesta was composed of one to two layers of radially elongated tabular to cuboid cells with cross-links on the dorsal surface of the pericline wall (Figs. 3B, C). The multiple layered endotesta was made up of four to five layers of cuboid cells (Figs. 3C, D). The embryo was in an erect position, dominant to total, developed and spatulate but folded in the shape of a razor. The cotyledons had foliaceous and expanded duplicates (Fig. 3A).

\section{Floral morphology and pollen characters}

The flowers of $T$. alata were solitary, axillary and erect. The calyx was gamosepalous with 15 lobes with moderate pubescence (10-30 trichomes $/ \mathrm{mm}^{2}$ ), erect filiform trichomes over the entire surface and scant pubescence $(<10$ tricho$\mathrm{mes} / \mathrm{mm}^{2}$ ) with glandular trichomes on the external face (Figs. 4E, G). The corolla was gamopetalous with five lobes that have a glabrous external face and an internal face with dense pubescence $\left(>30\right.$ trichomes $/ \mathrm{mm}^{2}$ ) of glandular trichomes (Figs. 4A, D, F).
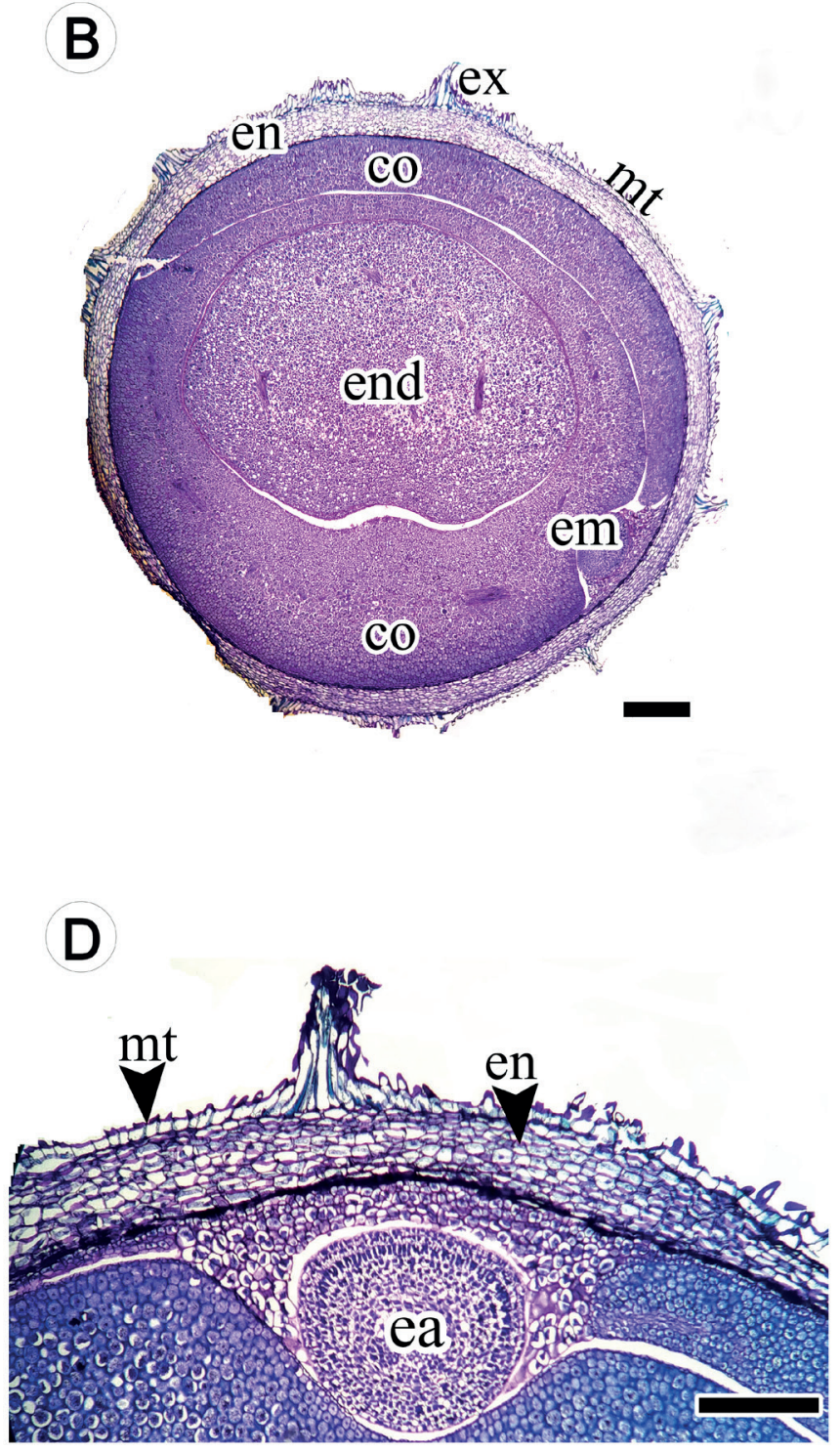

Figure 3: Longitudinal section of Thunbergia alata Bojer ex Sims seeds. A. longitudinal section showing the cotyledons; B. longitudinal section showing the endosperm; C. seed coat details; D. seed coat and embryo axis details, co = cotyledons, ea = embryo axis, en = endotestaend, = endosperm, em $=$ embryo, ex = exotesta, $\mathrm{mt}=$ mesotesta. Scale bar: $\mathrm{A}=100 \mu \mathrm{m}, \mathrm{B}-\mathrm{D}=500 \mu \mathrm{m}$. 


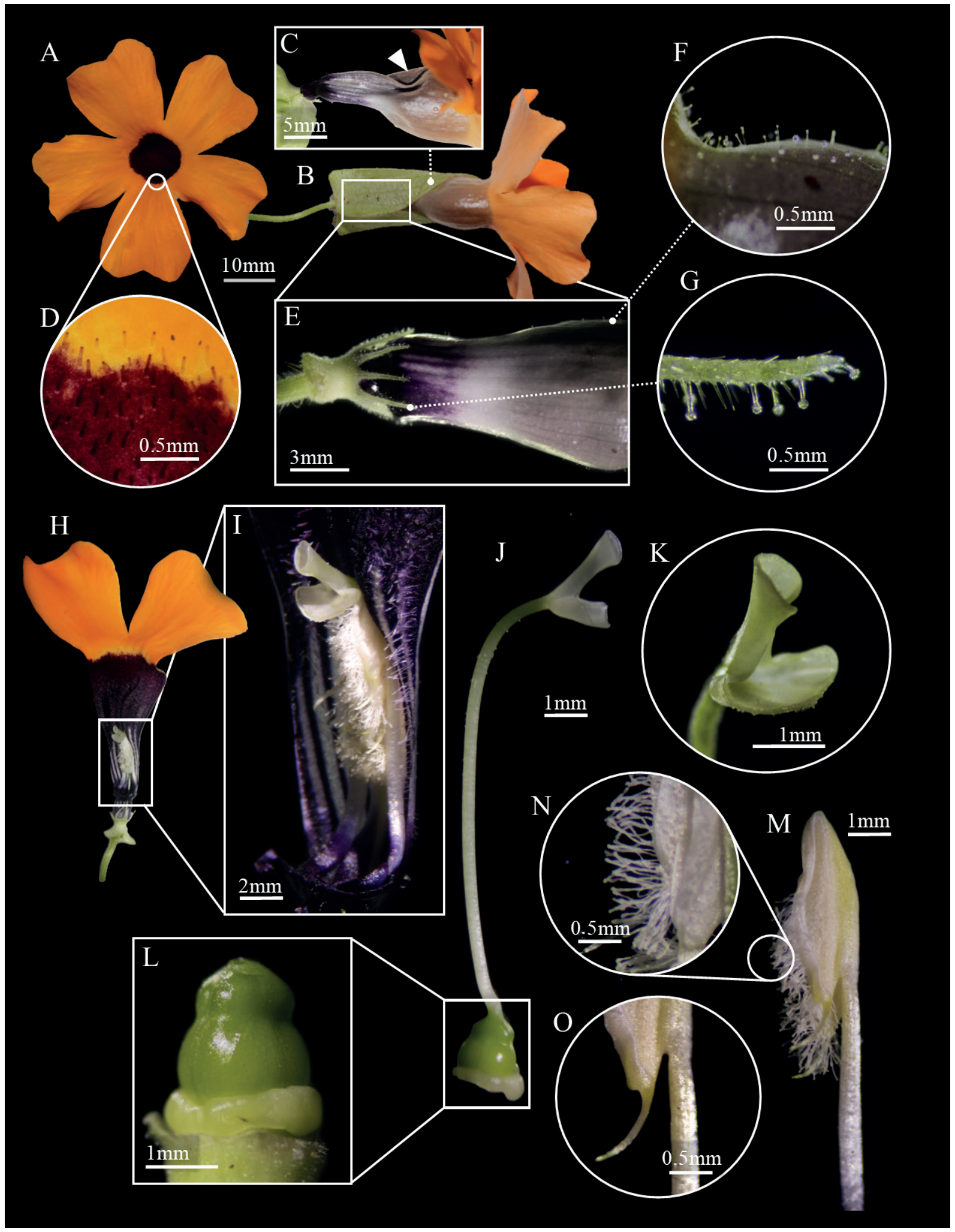

Figure 4: Floral morphology of Thunbergia alata Bojer ex Sims. A. frontal view of the corolla lobes; B. lateral view of the flower with the presence of floral bracts; $C$. approach to the external adaxial face of the corolla tube, the white triangle indicates two depressions on the mid-central region of the corolla; D. close-up in frontal view of the corolla lobes, the presence of glandular trichomes on the inner surface is highlighted; E. approach in lateral view to the base of the perianth, the floral bracts were dissected and removed; F. glandular trichomes on the outer surface of the corolla; G. filiform trichomes on the entire surface of the calyx and glandular trichomes on the outer surface of the lobes; H. section in transverse view of the corolla, internal reproductive structures are observed; I. approach to the internal face of the corolla, showing the position of the gynoecium and the androecium; J. lateral view of the gynoecium; K. approach to the stigma lobes, one elongated and folded inward and the other shorter and laterally extended; L. approach to the ovary; $\mathrm{M}$. Jateral view of one of the stamens; N. glandular trichomes on the dehiscence point of the anther; 0 . spur located at the base of the anther. 
The androecium was made up of four $12.2 \mathrm{~mm}$ inserted stamens located on the inner adaxial face (Fig. $4 \mathrm{H}$ ). The organization of the stamens along the interior of the corolla gave rise to a curtain of filaments that delimited a pollination chamber (Fig. 5). The curtain of filaments was composed of didynamous stamens that were grouped and fused in pairs, separated by the style located in the central part (Fig. 4I). This form of organization of the curtain was characterized by having decurrent filaments and inserts above the base of the corolla. Furthermore, because this curtain unfolds from the abaxial to the adaxial face of the corolla, the filaments formed a barrier over the nectaries located at the base. The anthers had a basifixed to slightly dorsifixed insertion with the presence of trichomes in the form of "barbs" located linearly on the abaxial face of the anther, above the dehiscence point, which is longitudinal, and two spurs in the basal part (Figs. 4M, N, O).

The gynoecium had a superior, globose, syncarpous ovary with two carpels and four locules. The upper part of the ovary had a globose extension that subsequently intervenes in the formation of the fruit (Fig. 4L). The style was glabrous and extended $15.9 \mathrm{~mm}$ (Fig. 4J). The stigma was bilobed, with the adaxial lobe longer and inwardly folded and the abaxial lobe shorter but extending laterally (Figs. 4J, K). This was located just above the anthers (Fig. 4I).

The pollen grain of $T$. alata was a large monad, $50.19(52.10) 53.96 \times 50,24(52.52) 54.80 \mu \mathrm{m}$ in equatorial

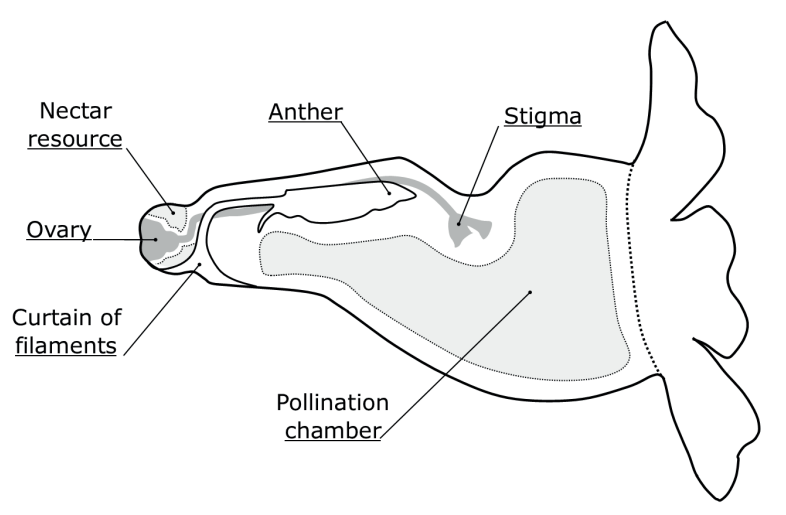

Figure 5: Diagram of the cross section of the flower highlighting structures involved in the pollination mechanism of Thunbergia alata Bojer ex Sims. view, 50.63(52.66)54, $69 \mu \mathrm{m}$ equatorial axis that was radial isopolar and an oblate-spheroidal shape, polar axis, and equatorial axis (P/E): 0.97 in the spheroidal domain. The grain had a colpo-spiral opening of $2.41 \mu \mathrm{m}$ wide, exine rough, tectate, $3.63 \mu \mathrm{m}$ thick, $2.48 \mu \mathrm{m}$ sexin, $1.60 \mu \mathrm{m}$ nexin (Fig. 6).

Pollen germination tests showed a higher germination percentage (90\%) for pollen grains exposed to concentrations of two percentage of sucrose. As the sucrose concentration was increased, the germination percentage decreased. The pollen tube was perceived after three minutes, being generated from the equatorial pole. In this area the tube originated from one or more points.

\section{Floral visitors}

A total of 1798 flowers were observed in 20 quadrants for 20 days and a total of 2266 flower visits were reported. Seven species classified as T. alata floral visitors were identified (Table 2). According to the frequency of flower visits, Bombus atratus Friese and Augochlora sp. (Fig. 7) had the highest frequency of visits throughout the sampling period. Of these two species, a total of 34 and 22 individuals were observed for 20 days, respectively. Visits of longer duration were observed for Apis mellifera L. and in a yet unidentified species of the family Nitidulidae, with three to four minutes respectively. The species with the shortest visit time were Bombus atratus and Augochlora sp. with one minute each.

Species such as $A$. mellifera and $B$. atratus were observed in direct contact with the reproductive organs of the flower, while other insects such as Augochlora sp. and Paratrigona sp. laid on the internal or external parts of the corolla. Individuals belonging to the families Nitidulidae and Curculionidae were found in external parts of the calyx or inside the base of the corolla.

\section{Fruit morphology and dehiscence}

Thunbergia alata has a dehiscent capsule-type fruit with 0.3$0.7 \mathrm{~cm}$ in diameter and $1.9-3.2 \mathrm{~cm}$ in length. The fruit originated from two globose carpels, each containing two seeds per loculum for a total of four seeds per fruit. On some occasions fewer seeds were found per fruit, possibly due to the fact that not all the ovules were fertilized. The fruit of $T$. alata has a flattened extension in the upper part of the carpels called the beak (Font Quer, 2001), 0.2-0.5 cm wide and 

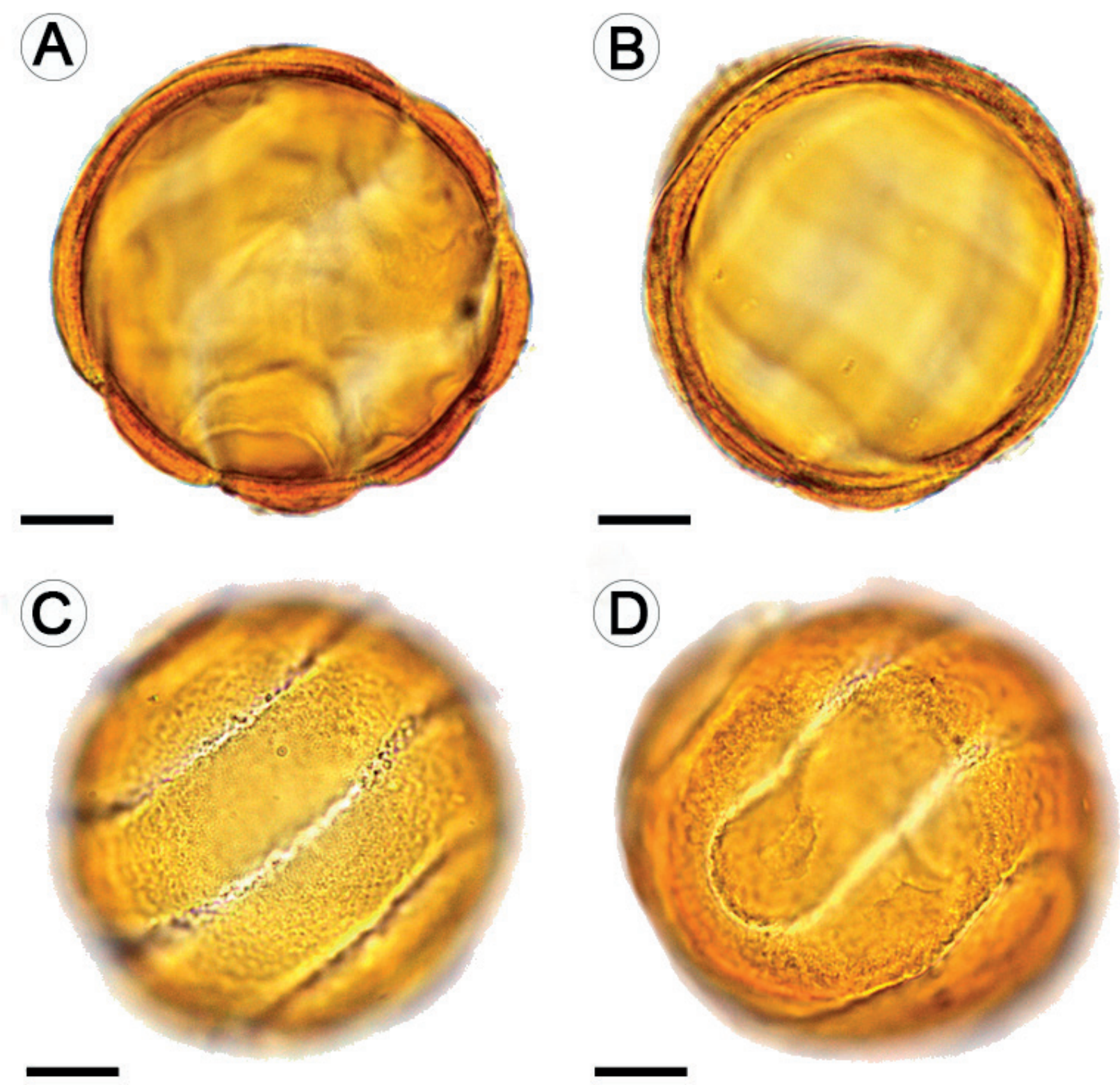

Figure 6: Pollen grain of Thunbergia alata Bojer ex Sims observed at 100x. A-C. equatorial view; D. polar view. A-B. structure of the cell wall. C-D. sculpture and ornamentation of the cell wall, openings (colpospiral). Scale bars $=10 \mu \mathrm{m}$.

Table 2: Insect species observed as floral visitors of Thunbergia alata Bojer ex Sims. The number of individuals of each species, observed throughout the sampling in Antioquia, Colombia, and the presence or absence of pollen grains on the surface of the organism are included.

\begin{tabular}{|c|c|c|c|c|c|}
\hline Order & Family & Species & $\begin{array}{c}\mathrm{N}^{\circ} \text { of individuals } \\
\text { observed }\end{array}$ & Presence of pollen & Origin \\
\hline Coleoptera & Curculionidae & Sitophilus sp. & 5 & Absent & Native \\
\hline Coleoptera & Endomychidae & - & 3 & Absent & Native \\
\hline Coleoptera & Nitidulidae & Conotelus sp. & 6 & Present & Native \\
\hline Hymenoptera & Apidae & Apis mellifera $\mathrm{L}$. & 24 & Present & Introduced \\
\hline Hymenoptera & Apidae & Bombus atratus Friese. & 34 & Present & Native \\
\hline Hymenoptera & Apidae & Paratrigona sp. & 10 & Present & Native \\
\hline Hymenoptera & Halictidae & Augochlora sp. & 22 & Present & Native \\
\hline
\end{tabular}



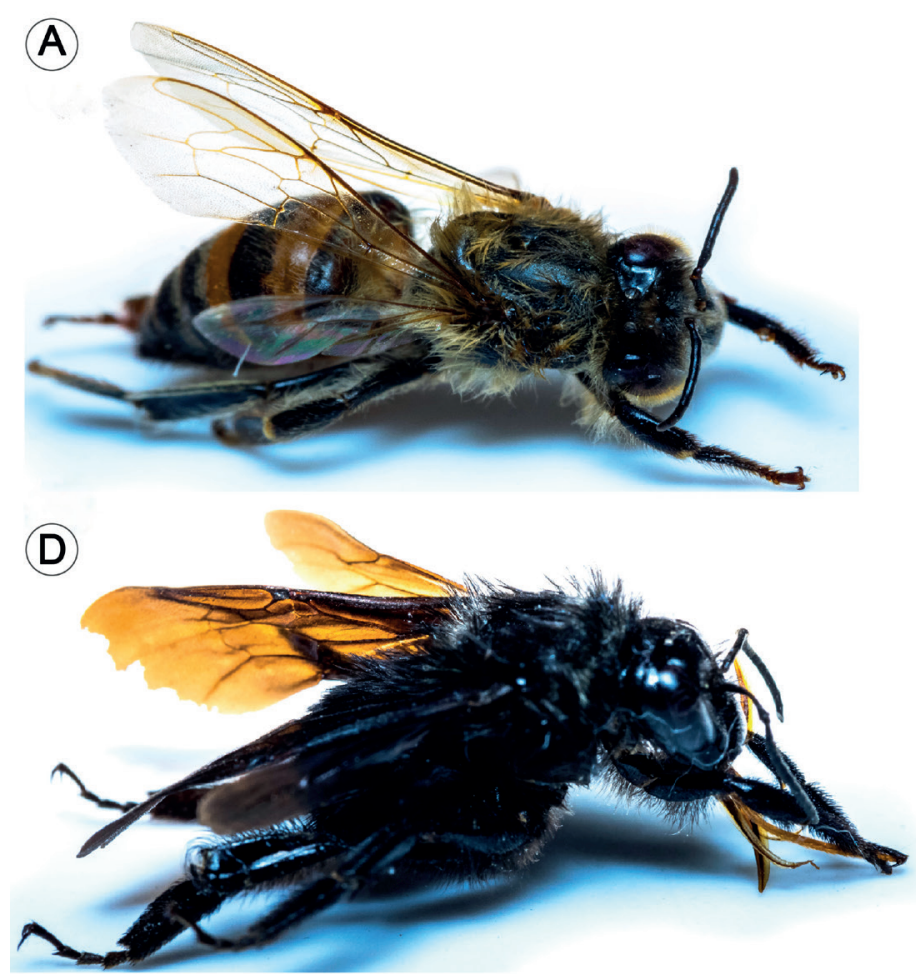

(E)

(B)

(C)

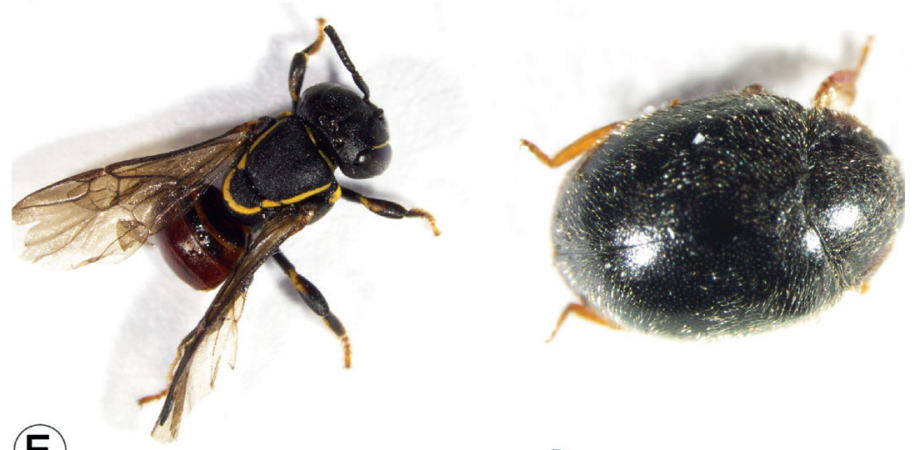

(F)
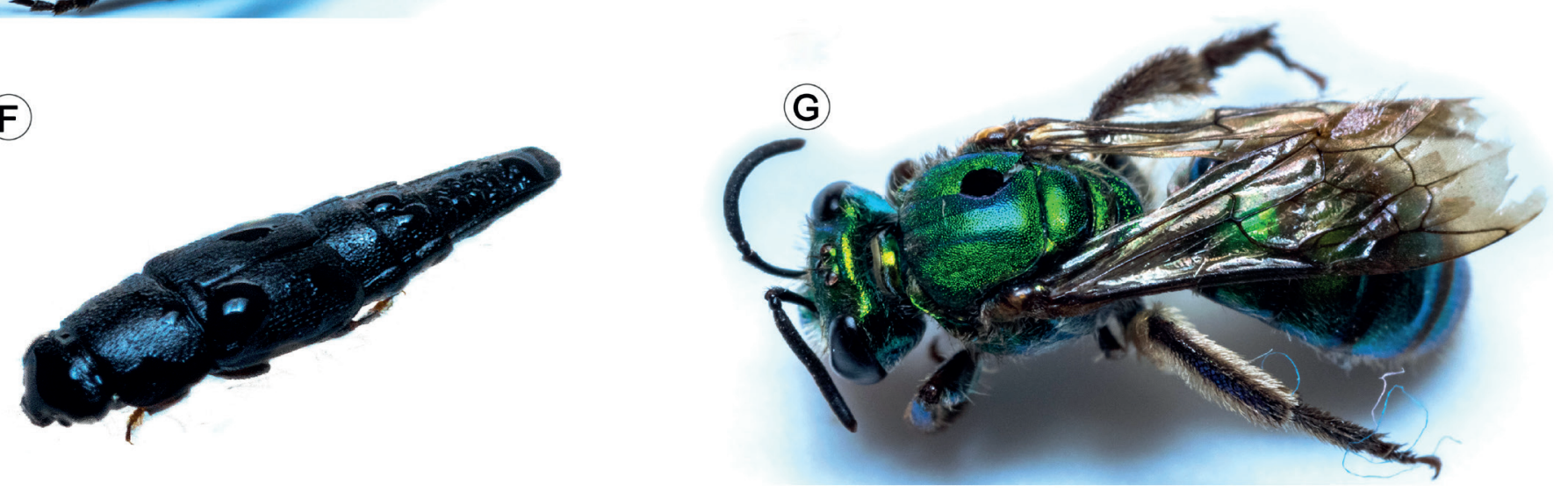

Figure 7: Floral visitors reported in the study: A. Apis mellifera L.; B. Paratrigona sp.; C. Endomychidae; D. Bombus atratus Friese; E. Sitophilus sp.; F. Conotelus sp.; G. Augochlora sp.

1-2 $\mathrm{cm}$ long, derived from the most distal section of the ovary. The entire external surface of the fruit had a high density of long trichomes. The average maturation time of the fruit was 15 days (Figs. 8C, D).

The dehiscence of the fruit was loculicidal since the division zone was located just above the carpel and not in the separation zone between them (the septum). A careful examination of the internal surface of the carpel, once dehiscence occurred, revealed the presence of remnants of the septum, indicating that this structure did not intervene in the dehiscence process (Fig. 9). The separation of the carpels began towards the most distal part of the fruit, with each section of the beak curving outwards (Figs. 8E, F). The accumulation of tension by twisting the sections of the face from the most distal part towards the middle part led to the separation of the fruit into two valves (Fig. $8 \mathrm{G}$ ). This event favoured the expulsion of the seeds like a catapult for 2 to $3 \mathrm{~m}$.

\section{The soil seed bank}

A total of 1480 seeds were found in the three sampled plots. The germination percentage was $100 \%$, at a maximum time of 72 hours (Table 3). The seeds extracted directly from $T$. alata fruits exhibited a reniform shape with 


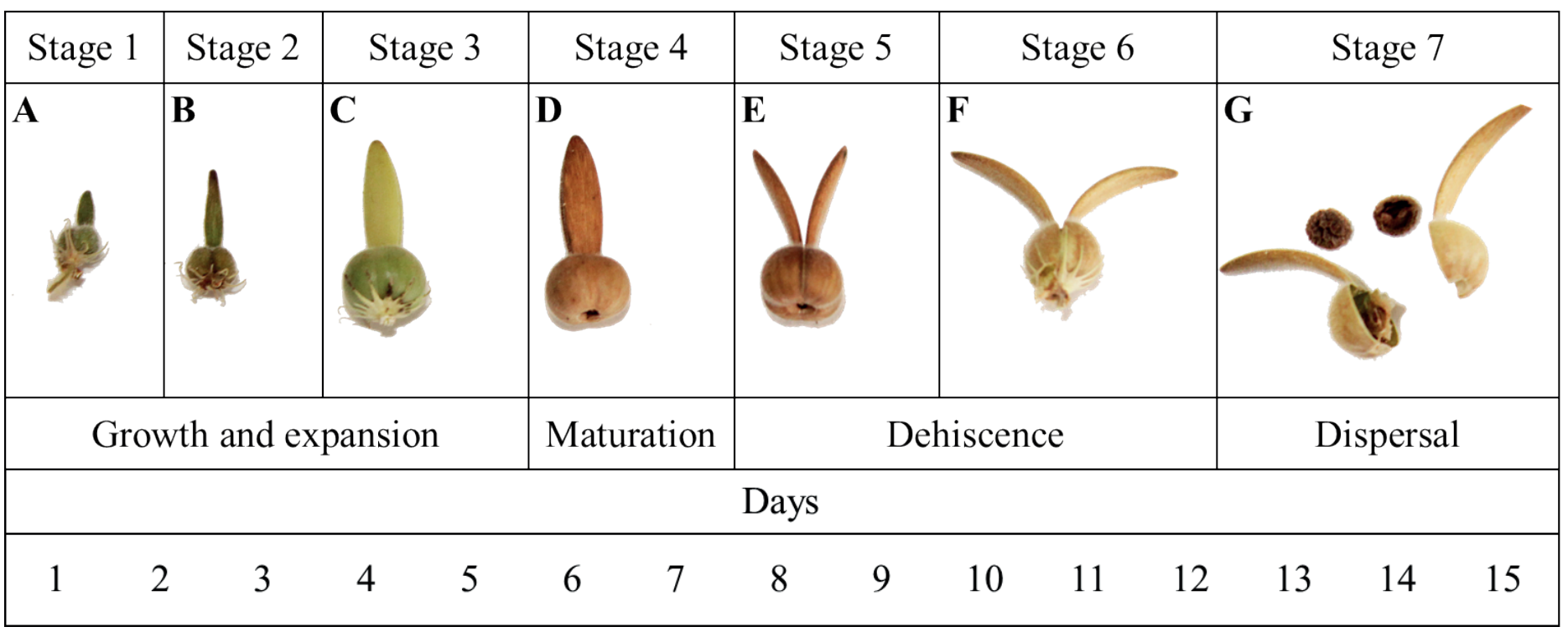

Figure 8: Developmental stages of the fruit of Thunbergia alata Bojer ex Sims, A-C. growth and expansion phase of the fruit, the ovary increases in size and the face elongates; D. fruit ripening phase, at this point the fruit undergoes physical and chemical changes that are evidenced in the coloration and the percentage of humidity; E-F. the fruit begins the dehiscence process by opening the valves that are separated by the apical region of the face; G. the fruit explodes and the seeds are dispersed, the lower scale in the figure shows the maturation time in days.

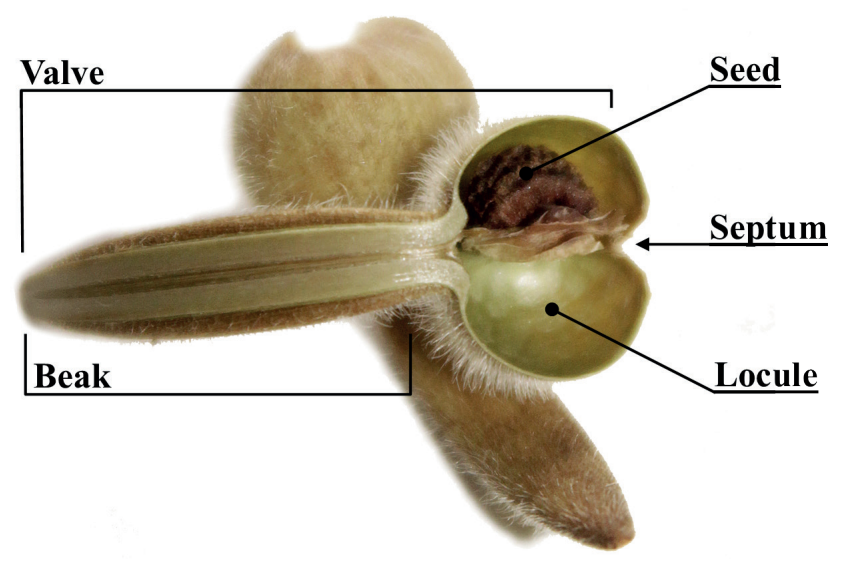

Figure 9: Internal view of a Thunbergia alata Bojer ex Sims fruit. The valve is made up of the beak and the basal part of the carpel. The septum can be observed and a seed still attached to the fruit.

a dark brown coloration of the testa (Fig. 10A). The ornamentation of the testa was characterized by a reticulate pattern with protuberances grouped in the form of ridges on both the dorsal and ventral surfaces (Figs. 10A, B). These ridges were generally interconnected forming concentric reticulations or rings that were sometimes discontinuous (Fig. 10A) (Balkwill and Campbell-Young, 1999).

In contrast, the seeds extracted from the soil had a light brown colour with advanced deterioration at the
Table 3: Mean germination time of Thunbergia alata Bojer ex Sims seeds (Antioquia, Colombia). $\mu=$ mean, $\mathrm{SD}=$ standard deviation, $\mathrm{CV}=$ coefficient of variation, $\mathrm{Min}=$ minimum value, $\mathrm{Max}=$ maximum value, MLG = Median Length of Germination time.

\begin{tabular}{ccccccc}
\hline Plot & $N^{\circ}$ seeds & $\begin{array}{c}\text { MLG } \pm S D \\
\text { (days) }\end{array}$ & CV & Min & Max & $\begin{array}{c}\text { germination } \\
(\%)\end{array}$ \\
\hline & & & & & & \\
1 & 150 & $2.67 \pm 1.55$ & 58.25 & 0.8 & 4.96 & 100 \\
2 & 150 & $2.67 \pm 2.03$ & 76.25 & 0.32 & 5.6 & 100 \\
3 & 150 & $2.67 \pm 1.69$ & 63.29 & 0.64 & 4.12 & 100 \\
Total & 450 & $2.67 \pm 1.70$ & 63.76 & 0.32 & 5.6 & \\
\hline
\end{tabular}

testa level (Fig. 10C). The ventral surface was much wider $(0.35 \mathrm{~mm})$ compared to the seeds extracted from the fruit $(0.2 \mathrm{~mm}$, Fig. 10D). The surface of the seeds extracted directly from the soil was completely smooth and of a lighter brown colour showing the successive wear of the testa because of its interaction with the soil microbiota. This would have a decisive influence on their rapid germination.

\section{Germination percentages}

From the germination tests carried out with the seeds extracted directly from the fruit under different light condi- 
tions we determined that the highest germination percentage occurred in treatment four (T4) with a value of $90 \%$ (Table 4). The lowest percentage occurred in treatment one (T1) with a value of $70 \%$ (Table 4). In general, there was no wide variation regarding the Median Length of Germination time, since the highest value was for T2 with 18.18 days and the minimum was for T3 with 16.48 days. A higher germination percentage was seen in low light conditions. However, the seedlings from the seeds subjected to T1 had a superior development of photosynthetic structures compared to those subjected to $\mathrm{T} 4$.
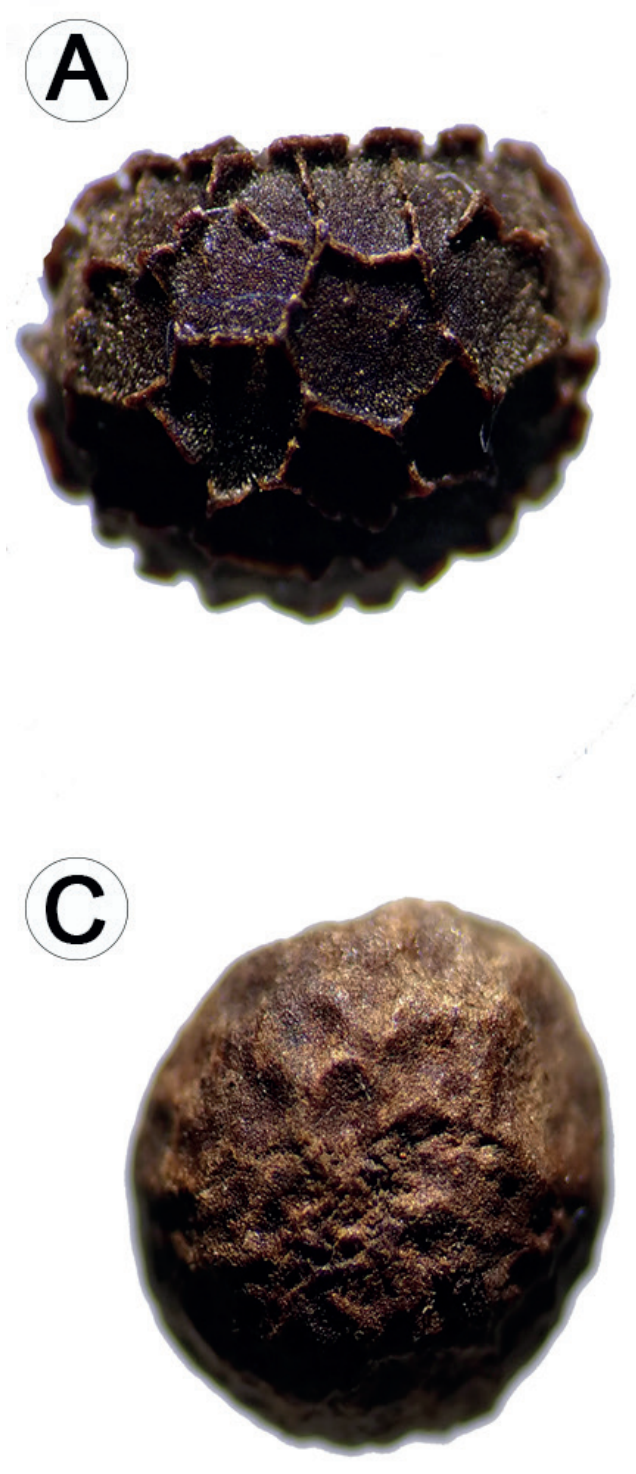

\section{Seedling functional morphology}

The morphological evaluation of the T. alata seedlings showed a phanerocotylar-epigeous-foliaceous morphological type. This type of seedling has two cotyledons located above the soil surface (epigeous cotyledons) that lose the seed coat during the germination process and are fully exposed (phanerocotyllary cotyledons). Besides, they had dorso-ventrally flattened sheets with a foliaceous appearance and that may have a moderate photosynthetic rate (foliaceous cotyledons). However, there were variations in the shape and size of the cotyledons: one of them was
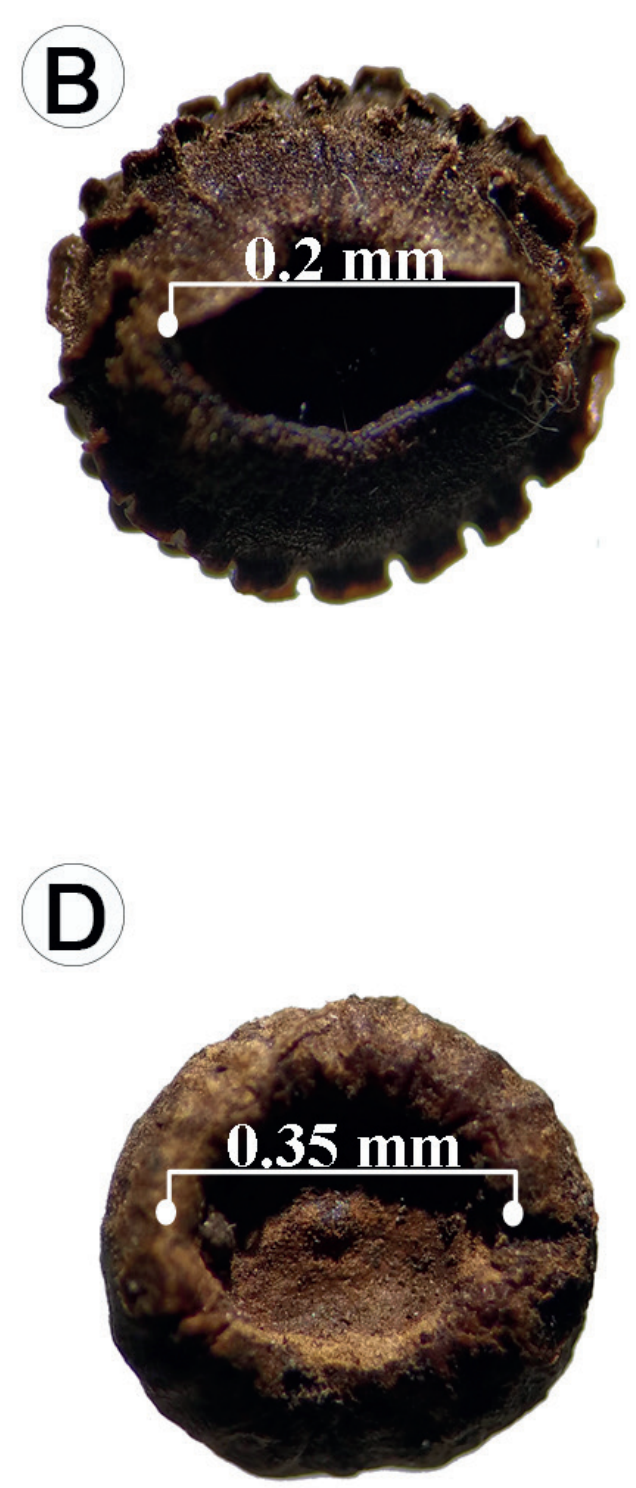

Figure 10: Morphology of Thunbergia alata Bojer ex Sims seeds: A-B. seeds extracted from the fruits; C-D. seeds collected in soil banks. 
Table 4: Median length of germination (MLG) and \% germination for each treatment of Thunbergia alata Bojer ex Sims (Antioquia, Colombia).

\begin{tabular}{cccc}
\hline $\begin{array}{c}\text { Luminosity } \\
\%\end{array}$ & $\begin{array}{c}\mathrm{N}^{\circ} \text { seeds } \\
\text { germinated }\end{array}$ & $\begin{array}{c}\text { MLG } \\
\text { (days) }\end{array}$ & $\begin{array}{c}\text { Germination } \\
\%\end{array}$ \\
\hline 100 & 35 & 17.57 & 70 \\
50 & 28 & 18.18 & 52 \\
25 & 39 & 16.48 & 78 \\
5 & 45 & 17.47 & 90 \\
\hline
\end{tabular}

thickened in the medial-central part of the lamina with a rounded apex, lobed base (with acute lobes). The other had a uniformly flattened blade with a rounded to slightly lobed apex and a truncated to rounded base.

Other relevant characters were the presence and density of trichomes in cotyledons, leaves and stems (hypocotyl and epicotyl). Cotyledon and foliar lamina presented moderate pubescence (10 to 20 trichomes $/ \mathrm{mm}^{2}$ ) of simple and short trichomes ( 0.125 to $0.5 \mathrm{~mm}$ in length) and the circular hypocotyl was $3.1-5.6 \mathrm{~cm}$ long, and $0.16-0.17 \mathrm{~cm}$ thick with dense pubescence $\left(>30\right.$ trichomes $/ \mathrm{mm}^{2}$ ) of simple and long trichomes (0.5 to $1.0 \mathrm{~mm}$ in length). The circular epicotyl measuring $0.17-0.18 \mathrm{~cm}$ thick and of variable length (phenotypically plastic), had moderate pubescence (10 to 20 trichomes $/ \mathrm{mm}^{2}$ ) of short trichomes (0.125 to 0.5 $\mathrm{mm}$ in length, Fig. 11). Also, active buds were observed in the axils of the cotyledons that developed branches during the early stages of seedling growth.

\section{Mycorrhizal symbiosis}

Spores associated with $T$. alata populations were found at all sites. The number of spores per $100 \mathrm{~g}$ of soil varied between 300 and 424 . All the roots of T. alata, without exception, had high colonization by arbuscular mycorrhizal fungi (Fig. 12). Similar values were observed at all sites, with a maximum value obtained from $69 \%$ mycorrhizal colonization.

\section{Discussion}

The study of the morphological, anatomical, and ecological characteristics is essential to understand the mechanisms of the dispersal, colonization, and establishment of an invasive species. However, ignorance of aspects of the life history of species such as T. alata is a limitation in biological control processes. This is a baseline investigation, with novel information on some functional traits that might contribute to a great extent to the high degree of colonization by $T$. alata in high Andean forests. From the results of the present research, various studies could be developed that address in a more detailed way each of the functional and life history traits described for this invasive species.

\section{Anatomical characters}

Although the morphological and reproductive traits are important, the anatomical traits which favour the adaptability of T. alata in different ecosystems cannot be ignored. Carlquist (1985a) states that the xylem segmentation pattern in the genus Thunbergia Retz helps to minimize the damage that the hydrosystem may have during water conduction. Likewise, although this plant has large vessels that increase the volume of water conduction per unit of time, it is possible that large vessels are more vulnerable to embolism (Carlquist, 1985a). However, the presence of vasicentric tracheids prevents the damage caused by an embolism from proportionally reducing the conduction of water, since this tissue, being smaller, has greater resistance to embolism and can continue its hydraulic activity even when the xylem vessels are inactive (Carlquist, 1985a, b; Carlquist and Zona, 1988; Gerolamo and Angyalossy, 2017; Naranjo et al., 2018). The abundant presence of parenchyma in the cylinder of $T$. alata surrounding the conductive tissues, guarantees the conduction of water, because the hydrolysis of starch inside the parenchyma cells, followed by the transfer of sugar to the vessels, generates osmotic pressures allowing an increase in the volume of water in the tracheids (Carlquist, 1985a, 2001; Carlquist and Zona, 1988). This factor suggests that the ability of $T$. alata to adapt to climatic conditions like those of the Colombian Andes, as well as to manual eradication, is precisely due to the advantages that this type of tissue is able to withstand mechanical damage and to maintain hydraulic activity through different mechanisms. The axial parenchyma gives flexibility to the stems of $T$. alata (Carlquist, 1985a), while the presence of lignified cells in the epidermis provides the mechanical capacity of the stems to show aggressive vegetative growth on any phorophyte. 
SEEDLING IN STAGE 2

First leaves

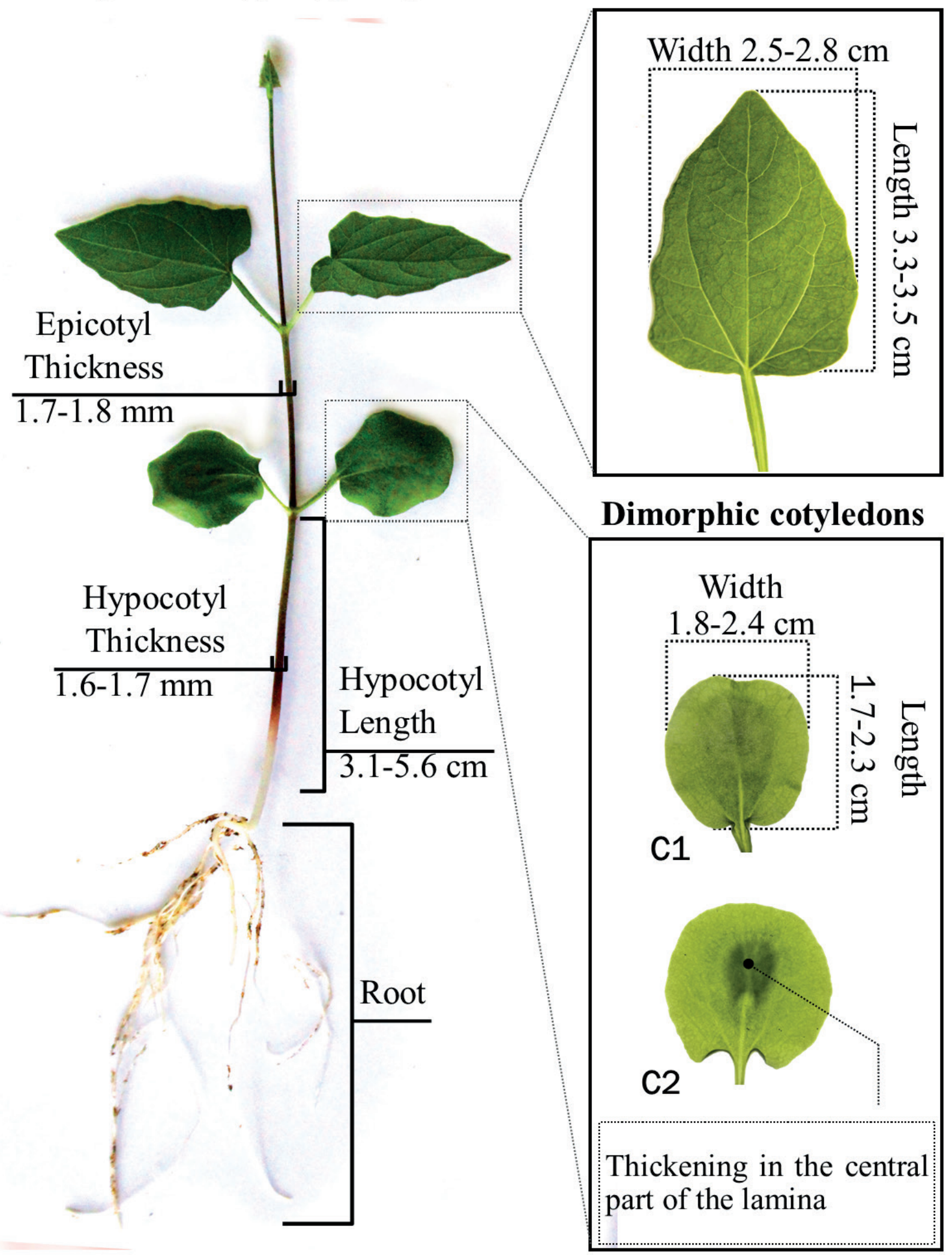

Figure 11: Characteristics of the Thunbergia alta Bojer ex Sims seedling and its measurements. 


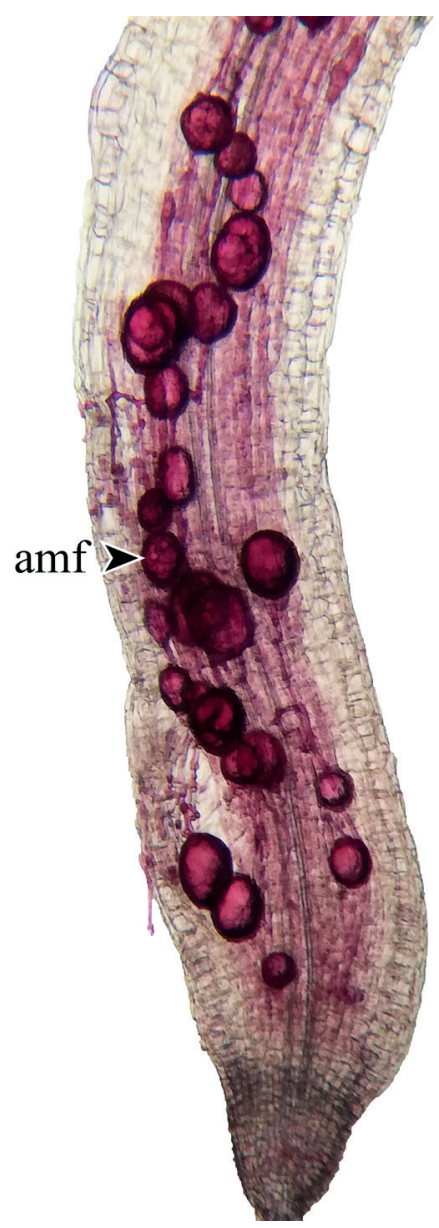

Figure 12: Root of Thunbergia alata Bojer ex Sims colonized by arbuscular mycorrhizal fungi (amf).

\section{Floral morphology and pollination}

The floral morphology exhibited by $T$. alata could have great importance for the number and diversity of floral visitors found. The results of this study show a notable difference in the length of the reproductive structures; the style is larger than the stamens $(3.7 \mathrm{~mm})$, which is related to an evolutionary mechanism that prevents self-pollination in angiosperms called herkogamy (Webb and Lloyd, 1986). Herkogamy and protandry have been suggested as two very common syndromes in the order Lamiales including the Acanthaceae (Endress, 1994; Nadia et al., 2012). The abundant filamentous trichomes located on the abaxial face of the anther could be involved in the dispersal of pollen grains (Figs. 4M, N, O) (Westerkamp and Claßen-Bockhoff, 2007). Many insects, especially bees, must apply considerable force to overcome this barrier when entering in search of nectar to access this resource, located at the base of the ovary. This continuous movement could cause adhesion of pollen to the dorsal surface of the insect due to friction with the anthers as barbs (Faegri and Van Der Pijl, 1979).

Manktelow (2000) suggests that the type of curtain of filaments of $T$. alata can only be overcome by large hymenopterans. These individuals could be considered effective pollinators, since when trying to open the curtain of filaments to access the nectar, they have direct contact with the anthers and the stigma. These insects include the species $B$. atratus and $A$. mellifera. The constant visit of effective pollinators allows $T$. alata to be succesfully be pollinated. Therefore, a constant generation of fruits and seeds throughout the year favours successful colonization (Thomson, 2006). Individuals belonging to the Curculionidae, Endomychidae and Nitidulidae and found in the samples are very small and generally feed on pollen and perianth. Therefore, they are considered less efficient pollinators. Thunbergia alata exhibits the Hymenoptera pollination syndrome since the style and the anthers have a closed adaxial fold, allowing the pollen to be deposited on the back of the insect (Schönenberger, 1999).

Frankie et al. (2005) studied the level of floral attraction of urban plant species concerning a certain group of pollinators. They found that, unlike what was stated in this study, native bees were not particularly attracted to exotic plants. In contrast, the results obtained in the present work are congruent with the proposal of González et al. (2005), that species such as B. atratus visit invasive exotic plants, among them T. alata, from which they obtain both nectar and pollen.

The pollen morphology of $T$. alata gives this species an advantage when it comes to fertilizing its ovules, mainly thanks to the spiral opening that surrounds all the pollen grains (Fig. 6). Furness (1985) states that this type of opening allows the pollen grains to have multiple germination sites and, therefore, exhibit a much higher germination rate. Even the germination rate can be increased by having an opening surrounding the pollen grain. This allows it to absorb water much faster (Furness and Rudall, 2004). 


\section{Dormancy and germination}

The high germination percentages of $T$. alata, together with a shorter period of seed germination, give the species the ability to colonize various habitats in short time, regardless of light conditions. This is consolidated as a strategy for effective regeneration. This strategy allows it to compete with sciophytic or heliophytic species, giving it an adaptive advantage (Kitajima and Fenner, 2000).

According to the viability and the morphological characteristics of the seeds extracted from the soil, T. alata may have the ability to form persistent seed banks. This in turn suggests a possible fluctuation between physiological dormancy states and the absence of dormancy in the seeds, depending on external factors. The high permeability of these seeds when exhibiting an exotesta with discontinuity in the arrangement of their cells, as well as the presence of a developed embryo, are characteristics commonly reported for species with physiological dormancy (Baskin and Baskin, 2014).

The dormancy cycle in T. alata can be attributed to the seed dispersal syndrome, since generally the autochory could cause the seeds to reach sites with adverse characteristics for germination and, therefore, develop physiological dormancy (Baskin and Baskin, 2014; Escobar et al., 2018). Generally, the cycles between physiological dormancy and a lack of dormancy occur in response to changes in light, temperature, or soil moisture (Baskin and Baskin, 2004). The results of this study show that different light gradients do not inhibit the germination of T. alata seeds; therefore, the seeds stored in soil may be physiologically dormant due to humidity or soil temperature conditions. Although dormancy is a factor that limits germination, it is also an evolutionary advantage that allows seeds to tolerate adverse scenarios until the ideal conditions for germination and seedling establishment are met (Vleeshouwers et al., 1995; Baskin and Baskin, 2014). Depending on the environmental conditions where the seed is located, T. alata can exhibit dormancy cycles without losing the viability of the seeds.

Garwood (1996), affirms that there is a relationship between this type of strategy and the morphological type of the seedling, where species with seedlings of the phanerocotylar-epigeous-foliaceous (PEF) and phanerocotylar-epigeous-reserve (PER) type are associated with higher germination percentages and faster seed germination. This association is known for the seedlings of invasive species (Sánchez and Quijano, 2020). It is also possible that this strategy is associated with other characteristics related to the early development of the seedling, such as the time required for the expansion of the first photosynthetic organs, the growth rate, or the increase in biomass of the seedling in its first stages.

Thunbergia alata seedlings show pubescence with a high density of trichomes and a high percentage of germination. Studies show that the presence of trichomes in the epidermis of stems and leaves confers adaptive advantages in higher stress environmental contexts through the combination of physical, mechanical or biochemical protection strategies, especially in developing organs of tropical species (Karabourniotis et al., 2020), where the high density of non-glandular trichomes is related to protection against drastic drought conditions and high light intensities (Pringle et al., 2011; Ichie et al., 2016) This could indicate that the presence of a high density of non-glandular trichomes in invasive species could translate into a greater tolerance to environments with a higher incidence of light and high temperatures.

\section{Mycorrhizal symbiosis}

Although there are no known studies of mycorrhizal response or dependence in T. alata (Plenchette et al., 1983; Habte and Manjunath, 1991), the results obtained in this research reveal high infectivity in all the evaluated plants (Fig. 12), with values higher than $60 \%$, data that generally belong to dependent plant species (Habte and Manjunath, 1991; Siqueira and Saggin-Júnior, 2001). These values suggest that $T$. alata uses all the benefits of symbiosis with arbuscular mycorrhizal fungi for its survival, allowing the plant a better exploration of the soil in search of nutrients. The hyphae of the fungus have a smaller diameter and greater extension (Bolan, 1991) and can be in places in the soil that absorbent hairs cannot reach (Johansen et al., 1993), facilitating the uptake of slowly diffusing nutrients such as phosphorus (Sieverding, 1991; Jakobsen et al., 1992). Arbuscular mycorrhizal fungus not only improve the nutrition of $T$. alata, but they can also help the plant tolerate water stress (Brundrett, 2009), and better resist attack by soil- 
borne pathogens (Sierra-Escobar et al., 2017). All these advantages make $T$. alata improve its invasive capacity.

The findings of the present study suggest that floral traits such as the curtain of filaments, the organization of the gynoecium, and the androecium, as well as the characteristics of the pollen grain, give $T$. alata the ability to produce seeds at different times and in high quantities. Additionally, high germination percentages, as well as the possibility of forming persistent seed banks, could contribute to the high invasiveness of this species. The morphological characteristics of the initial stages and the anatomical characteristics related to the growth habit could improve the ability of $T$. alata to adapt and compete, conferring a high tolerance for drastic environmental changes and maximizing its invasive potential. Finally, the different associations of this invasive plant with native species, both pollinators and the megadiversity of soil organisms including mycorrhiza-forming fungi, could contribute significantly to the success of this species in our native Andean environments. Without doubt, $T$. alata has been able to adapt optimally to the new and diverse scenarios of our ecosystems. The results obtained here open new perspectives that could contribute to an understanding of the invasive abilities of T. alata. The results presented here may contribute to the development of different lines of research that lead to a better design in the control and management of actions of this invasive species.

\section{Author contributions}

MACL and MAQA conceived and designed the study. MACL, $D M H, D S G$, and JMRV made the collections. MACL, DMH, DSG, MR, and JSE contributed to the acquisition of important data for the job. The photographs were taken by MACL, DMH, DSG and MR. All authors wrote the manuscript and contributed to the discussion, review, and approval of the final manuscript.

\section{Funding}

This research was funded by the Corporación Autónoma Regional de las Cuencas de los Ríos Negro y Nare (CORNARE) and the Universidad Católica de Oriente under agreement 377 of 2019.

\section{Acknowledgements}

The authors thank the director of the extension and social projection and the center for territorial studies of the Universidad Católica de Oriente for their logistical and administrative support in the research. Likewise, we thank the Corporación Autónoma Regional de las Cuencas de los Ríos Negro y Nare (CORNARE) for their financial support.

\section{Literature cited}

Alzate, F., M. Gómez and S. Rodríguez. 2008. Especies vegetales del altiplano del Oriente antioqueño en peligro de extinción, 1st ed. Lealon. Medellín, Colombia.

Angyalossy, V., M. R. Pace and A. C. Lima. 2015. Liana anatomy: a broad perspective on structural evolution of the vascular system. In: Schnitzer, S. A., Bongers, F., R. J. Burnham and F. E. Putz (eds.). Ecology of Lianas. John Wiley \& Sons, Ltd., Chichester, UK. Pp. 251-287. DOI: https://doi. org/10.1002/9781118392409.ch19

Armenteras, D., F. Gast and H. Villareal. 2003. Andean forest fragmentation and the representativeness of protected natural areas in the eastern Andes, Colombia. Biological Conservation 113(2): 245-256. DOI: https://doi.org/10.1016/s00063207(02)00359-2

Arslan, Z. F., A. Uludag and I. Uremis. 2015. Status of invasive alien plants included in EPPO Lists in Turkey. EPPO Bulletin 45(1): 66-72. DOI: https://doi.org/10.1111/EPP.12176

Balkwill, K. and G. Campbell-Young. 1999. Taxonomic studies in Acanthaceae: Testa microsculpturing in southern African species of Thunbergia. Botanical Journal of the Linnean Society 131(3): 301-325. DOI: https://doi.org/10.1006/ bojl.1999.0281

Baptiste, M. P., N. Castaño, C. Lasso, D. Cárdenas, F. D. Gutiérrez and D. L. Gil. 2010. Análisis de riesgo y propuesta de categorización de especies introducidas para Colombia. Instituto de Investigación de Recursos Biológicos Alexander von Humboldt. Bogotá, D.C., Colombia. Pp. 149-194.

Baskin, C. and J. Baskin. 2004. Determining dormancy-breaking and germination requirements from the fewest seeds. In: Guerrant, E. O., K. Havens-Young and M. Maunder (eds.). Ex Situ Plant Conservation: Supporting Species Survival in the Wild. Island Press. Washington, D.C., USA. Pp. 162-179.

Baskin, C. and J. Baskin. 2014. Seeds: ecology, biogeography, and evolution of dormancy and germination. Academic Press. 
San Diego, USA. 1601 pp. DOI: https://doi.org/10.1016/ C2013-0-00597-X

Bolan, N. S. 1991. A critical review on the role of mycorrhizal fungi in the uptake of phosphorus by plants. Plant and Soil 134: 189-207. DOI: https://doi.org/10.1007/BF00012037

Brundrett, M. C. 2009. Mycorrhizal associations and other means of nutrition of vascular plants: Understanding the global diversity of host plants by resolving conflicting information and developing reliable means of diagnosis. Plant and Soil 320: 37-77. DOI: https://doi.org/10.1007/s11104-008-9877-9

Campoy, J. G., A. T. Acosta, L. Affre, R. Barreiro, G. Brundu, E. Buisson, L. González, M. Lema, A. Novoa, R. Retuerto, S. R. Roiloa and J. Fagúndez. 2018. Monographs of invasive plants in Europe: Carpobrotus. Botany Letters 165(3-4): 440-475. DOI: https://doi.org/10.1080/23818107.2018.1487884

Cárdenas-López, D., M. P. Baptiste and N. Castaño. 2017. Plantas exóticas con alto potencial de invasión en Colombia. Instituto de Investigación de Recursos Biológicos Alexander von Humboldt. Bogotá, D.C., Colombia. Pp. 25-71.

Carlquist, S. 1985a. Observations on functional wood histology of vines and lianas. Aliso 11(2): 139-157. DOI: https://doi. org/10.5642/aliso.19851102.03

Carlquist, S. 1985b. Vasicentric tracheids as a drought survival mechanism in the woody flora of southern California and similar regions; review of vasicentric tracheids. Aliso 11(1): 37-68.

Carlquist, S. 2001. Comparative wood anatomy: systematic, ecological, and evolutionary aspects of dicotyledon wood. 2nd ed. Springer-Verlag. Berlin, Heidelberg, Germany. Pp. 45-67. DOI: https://doi.org/10.1007/978-3-662-04578-7

Carlquist, S. and S. Zona. 1988. Wood anatomy of Acanthaceae: a survey. Aliso 12(1): 201-227. DOI: https://doi.org/10.5642/ aliso.19881201.15

D’Antonio, C. M., N. E. Jackson, C. C. Horvitz and R. Hedberg. 2004. Invasive plants in wildland ecosystems: Merging the study of invasion processes with management needs. Frontiers in Ecology and the Environment 2(10): 513-521. DOI: https:// doi.org/10.2307/3868381

Endress, P. 1994. Diversity and evolutionary biology of tropical flowers. Cambridge University Press. Cambridge, UK. Pp. 328-335.

Erdtman, G. 1969. Handbook of palynology: Morphology, taxonomy, ecology. An introduction to the study of pollen grains and spores. Scandinavian University Books. Oslo, Norway. Pp. 21-80.

Escobar, D. F., F. A. Silveira and L. P. Morellato. 2018. Timing of seed dispersal and seed dormancy in Brazilian savanna: Two solutions to face seasonality. Annals of Botany 121(6): 11971209. DOI: https://doi.org/10.1093/aob/mcy006

Ewers, F., J. Fisher and K. Fichtner. 1992. Water flux and xylem structure in vines. In: Putz, F. E. and H. A. Mooney (eds.). The Biology of Vines. Cambridge University Press. Cambridge, UK. Pp. 127-160. DOI: https://doi.org/10.1017/ CBO9780511897658.007

Faegri, K. and L. Van Der Pijl. 1979. The Principles of Pollination Ecology. Elsevier. London, UK. Pp. 142-150.

Font Quer, P. 2001. Diccionario de botánica, $2^{\mathrm{a}}$ ed. Ediciones Península. Barcelona, España. Pp. 120-135.

Frankie, G. W., R. W. Thorp, M. Schindler, J. Hernandez, B. Ertter and M. Rizzardi. 2005. Ecological patterns of bees and their host ornamental flowers in two northern California cities. Journal of the Kansas Entomological Society 78(3): 227-246. DOI: https://doi.org/10.2317/0407.08.1

Furness, C. A. 1985. A review of spiraperturate pollen. Pollen et Spores 27(3-4): 307-319.

Furness, C. A. and P. J. Rudall. 2004. Pollen aperture evolution - A crucial factor for eudicot success? Trends in Plant Science 9(3): 154-158. DOI: https://doi.org/10.1016/j.tplants.2004.01.001

García-Duque, J. J., M. C. Franco-Ospina, D. E. Cardona-Ramírez and M. A. Quijano-Abril. 2016. Categorización y análisis de la distribución de especies introducidas, establecidas e invasoras en el altiplano del Oriente Antioqueño. In: Quijano-Abril, M. A (ed.). Flora Del Oriente Antioqueño: Biodiversidad, Ecología y Estrategías de Conservación. Fondo Editorial Universidad Católica de Oriente. Bogotá, D.C., Colombia. Pp. 109-132.

García, L., M. Rivero and F. Droppelmann. 2015. Descripción morfológica y viabilidad del polen de Nothofagus nervosa (Nothofagaceae). Bosque 36(3): 487-496. DOI: https://doi. org/10.4067/S0717-92002015000300015

Garwood, N. 1996. Functional morphology of tropical tree seedlings. In: Swaine, M. D. (ed.). The Ecology of Tropical Forest Tree Seedling. The United Nations Educational, Scientific and Cultural Organization (UNESCO). Paris, France. Pp. 59-129.

Garwood, N., M. Tebbs and R. B. Foster. 2009. Seedlings of Barro Colorado Island and the Neotropics. Comstock Publishing Associates, Cornell University Press. Ithaca, USA. Pp. 35-120. 
Gerolamo, C. S. and V. Angyalossy. 2017. Wood anatomy and conductivity in lianas, shrubs and trees of Bignoniaceae. IAWA Journal 38(3): 412-432. DOI: https://doi. org/10.1163/22941932-20170177

Giovannetti, M. and B. Mosse. 1980. An evaluation of techniques for measuring vesicular arbuscular mycorrhizal infection in roots. New Phytologist 84(3): 489-500. DOI: https://doi. org/10.1111/j.1469-8137.1980.tb04556.x

Gómez, A., J. C. Berrío, H. Hooghiemstra, M. Becerra and R. Marchant. 2007. A Holocene pollen record of vegetation change and human impact from Pantano de Vargas, an intra-Andean basin of Duitama, Colombia. Review of Palaeobotany and Palynology 145(1-2): 143-157. DOI: https://doi. org/10.1016/J.REVPALBO.2006.10.002

González-Orozco, C. E. 2021. Biogeographical regionalisation of Colombia: A revised area taxonomy. Phytotaxa 484(3): 247260. DOI: https://doi.org/10.11646/phytotaxa.484.3.1

González, V., M. Ospina and D. Bennett. 2005. Abejas altoandinas de Colombia: guía de campo. Instituto de Investigación de Recursos Biológicos Alexander von Humboldt. Bogotá, D.C., Colombia. Pp. 35-68.

Gutiérrez, F. 2006. Estado de conocimiento de especies invasoras: Propuesta de lineamientos para el control de los impactos. Instituto de Investigación de Recursos Biológicos Alexander von Humboldt. Bogotá, D.C., Colombia. Pp. 45-94.

Habte, M. and A. Manjunath. 1991. Categories of vesicular-arbuscular mycorrhizal dependency of host species. Mycorrhiza 1: 3-12. DOI: https://doi.org/10.1007/BF00205896

Habte, M. and N. Osorio. 2001. Arbuscular mycorrhizas: producing and applying arbuscular mycorrhizal inoculum. University of Hawaii. Hawaii, USA. Pp. 3-42.

Halbritter, H., S. Ulrich, F. Grímsson, M. Weber, R. Zetter, M. Hesse, R. Buchner, M. Svojtka and A. Frosch-Radivo. 2018. Illustrated pollen terminology. Springer Nature. Cham, Switzerland. Pp. 15-35. DOI: https://doi.org/10.1007/9783-319-71365-6

Hegland, S. J. and $\varnothing$. Totland. 2005. Relationships between species' floral traits and pollinator visitation in a temperate grassland. Oecologia 145: 586-594. DOI: https://doi. org/10.1007/s00442-005-0165-6

Holdridge, L. R. 1967. Life zone ecology. Tropical Science Center. San José, Costa Rica. Pp. 7-13.
Ichie, T., Y. Inoue, N. Takahashi, K. Kamiya and T. Kenzo. 2016. Ecological distribution of leaf stomata and trichomes among tree species in a Malaysian lowland tropical rain forest. Journal of Plant Research 129: 625-635. DOI: https://doi. org/10.1007/s10265-016-0795-2

IDEAM, 2005. Cartas climatológicas - medidas mensuales. Climatología de las Principales Ciudades. http://www.ideam.gov.co/ web/tiempo-y-clima/climatologico-mensual (consulted June, 2019).

IGAC. 2019. MAGNA-SIRGAS, Marco Geocéntrico Nacional de Referencia, densificación del Sistema de Referencia Geocéntrico para las Américas. Instituto Geográfico Agustín Codazzi. Bogotá, Colombia. https://www.igac.gov.co/es/contenido/areasestrategicas/magna-sirgas (consultado diciembre de 2019).

Jakobsen, I., L. K. Abbott and A. D. Robson. 1992. External hyphae of vesicular-arbuscular mycorrhizal fungi associated with Trifolium subterraneum L. 1. Spread of hyphae and phosphorus inflow into roots. New Phytologist 120(3): 371-380. DOI: https://doi.org/10.1111/j.1469-8137.1992.tb01077.x

Jaramillo, F. 2017. Las 35 plantas exóticas con alto potencial de invasión de Colombia. http://www.humboldt.org.co/es/boletines-y-comunicados/item/1108-35-plantas-exoticas-invasion-colombia (consulted August, 2019).

Johansen, A., I. Jakobsen and E. S. Jensen. 1993. External hyphae of vesicular-arbuscular mycorrhizal fungi associated with Trifolium subterraneum L. 3. Hyphal transport of $32 \mathrm{P}$ and 15N. New Phytologist 124(1): 61-68. DOI: https://doi. org/10.1111/j.1469-8137.1993.tb03797.x

Karabourniotis, G., G. Liakopoulos, D. Nikolopoulos and P. Bresta. 2020. Protective and defensive roles of non-glandular trichomes against multiple stresses: structure function coordination. Journal of Forestry Research 31: 1-12. DOI: https:// doi.org/10.1007/s11676-019-01034-4

Kitajima, K. and M. Fenner. 2000. Ecology of seedling regeneration. In: Fenner, M. (ed.). Seeds: The Ecology of Regeneration in Plant Communities. London, UK. Pp. 331-359. DOI: https://doi.org/10.1079/9780851994321.0331

Kormanik, P. P., W. C. Bryan and R. C. Schultz. 1980. Procedures and equipment for staining large numbers of plant root samples for endomycorrhizal assay. Canadian Journal of Microbiology 26(4): 536-538. DOI: https://doi.org/10.1139/ m80-090 
Lockwood, J. L., P. Cassey and T. Blackburn. 2005. The role of propagule pressure in explaining species invasions. Trends in Ecology and Evolution 20(5): 223-228. DOI: https://doi. org/10.1016/j.tree.2005.02.004

López-García, M. M., D. M. Méndez-Rojas and R. García Cárdenas. 2011. Staphylinidae y Nitidulidae (Coleoptera) asociados a inforescencias de Etlingera elatior (Zingiberaceae). Revista Colombiana de Entomología 37(1): 357-359.

Mack, R., D. Simberloff, M. Lonsdale, H. Evans, M. Clout and F. Bazzaz. 2000. Biotic invasions: causes, epidemiology, global consequences, and control. Ecological Applications 10(3): 689-710. DOI: https://doi.org/10.1890/1051-0761(2000)010 [0689:BICEGC]2.0.CO;2

Manktelow, M. 2000. The filament curtain: A structure important to systematics and pollination biology in the Acanthaceae. Botanical Journal of the Linnean Society 133(2): 129-160. DOI: https://doi.org/10.1006/bojl.1999.0309

Martin, A. 1946. The comparative internal morphology of seeds. The University of Notre Dame 36(3): 513-560. DOI: https:// doi.org/https://doi.org/10.2307/2421457

Meyer, J. Y. and C. Lavergne. 2004. Beautés fatales: Acanthaceae species as invasive alien plants on tropical Indo-Pacific Islands. Diversity and Distributions 10(5-6): 333-347. DOI: https://doi.org/10.1111/J.1366-9516.2004.00094.X

Nadia, T. D., N. L. De Menezes and I. C. Machado. 2012. Floral traits and reproduction of Avicennia schaueriana Moldenke (Acanthaceae): A generalist pollination system in the Lamiales. Plant Species Biology 28(1): 70-80. DOI: https://doi. org/10.1111/j.1442-1984.2011.00361.x

Naranjo, J. P., M. Torres and M. A. Quijano. 2018. On growth habits and forms: the utility of stem anatomy to define growth habits of Melastomataceae. Acta Botanica Mexicana 123: 1-45. DOI: https://doi.org/10.21829/abm123.2018.1245

Ocampo-Zuleta, K. and J. Solorza-Bejarano. 2017. Banco de semillas de retamo espinoso Ulex europaeus L. en bordes del matorral invasor en un ecosistema zonal de bosque altoandino. Colombia. Biota Colombiana 18(1): 99-109. DOI: https://doi. org/10.21068/c2017v18s01a05

Olden, J. D. and N. L. Poff. 2003. Toward a mechanistic understanding and prediction of biotic homogenization. The American Naturalist 162(4): 442-460. DOI: https://doi. org/10.1086/378212
Pérez-Bedmar, M. and V. Sanz-Pérez. 2003. Educación ambiental y especies exóticas: desde las normativas globales hasta las acciones locales. Ecosistemas, Revista Científica de Ecología y Medio Ambiente 12(3): 1-5.

Phillips, J. and D. Hayman. 1970. Improved procedures for clearing roots and staining parasitic and vesicular-arbuscular mycorrhizal fungi for rapid assessment of infection. Transactions of the British Mycological Society 55(1): 158-161. DOI: https:// doi.org/10.1016/s0007-1536(70)80110-3

Plenchette, C., J. A. Fortin and V. Furlan. 1983. Growth responses of several plant species to mycorrhizae in a soil of moderate P-fertility - I. Mycorrhizal dependency under field conditions. Plant and Soil 70: 199-209. DOI: https://doi.org/10.1007/ BF02374780

Pringle, E. G., R. I. Adams, E. Broadbent, P. E. Busby, C. I. Donatti, E. L. Kurten, K. Renton and R. Dirzo. 2011. Distinct leaf-trait syndromes of evergreen and deciduous trees in a seasonally dry tropical forest. Biotropica 43(3): 299-308. DOI: https:// doi.org/10.1111/j.1744-7429.2010.00697.x

R Core Team. 2019. R: A language and environment for statistical computing. R Foundation for Statistical Computing. Vienna, Austria. https://www.r-project.org/ (consulted August, 2021).

Raczka, M. F., N. A. Mosblech, L. Giosan, B. G. Valencia, A. M. Folcik, M. Kingston, S. Baskin and M. B. Bush. 2019. A human role in Andean megafaunal extinction? Quaternary Science Reviews 205: 154-165. DOI: https://doi.org/10.1016/J.QUASCIREV.2018.12.005

Ríos, H. and O. Vargas. 2003. Ecología de las especies invasoras. Jardín Botánico José Celestino Mutis 14: 119-148.

Ruiz, T. E., J. Alonso, N. Valenciaga, G. Febles, S. Lok, J. Galindo, H. Díaz and A. Lopez. 2018. Relation between management and Leucaena (Leucaena leucocephala) to prevent its transformation into an invasive plant. Cuban Journal of Agricultural Science 52(1): 87-95.

Saatkamp, A., A. Cochrane, L. Commander, L. K. Guja, B. Jiménez-Alfaro, J. Larson, A. Nicotra, P. Poschlod, F. A. Silveira, A. T. Cross, E. L. Dalziell, J. Dickie, T. E. Erickson, A. Fidelis, A. Fuchs, P. J. Golos, M. Hope, W. Lewandrowski, D. J. Merritt, B. P. Miller, R. G. Miller, C. A. Offord, M. K. Ooi, A. Satyanti, K. D. Sommerville, R. Tangney, S. Tomlinson, S. Turner and J. L. Walck. 2019. A research agenda for seed-trait functional ecol- 
ogy. New Phytologist 221(4): 1764-1775. DOI: https://doi. org/10.1111/nph.15502

Sakai, A. K., F. W. Allendorf, J. S. Holt, M. Lodge, J. Molofsky, K. A. With, R. J. Cabin, J. E. Cohen, C. Norman, D. E. McCauley, P. O. Neil, M. Parker, J. N. Thompson and S. G. Weller. 2001. The population biology of invasive species. Annual Review of Ecology, Evolution and Systematics 32: 305-332. DOI: https:// doi.org/10.1146/annurev.ecolsys.32.081501.114037

Sánchez, D. and M. A. Quijano. 2020. Caracterización morfológica de plántulas de angiospermas en bosques Altoandinos del oriente Antioqueño. Memorias X Congreso Colombiano de Botánica. Medellín, Colombia. Pp. 1-30.

Schönenberger, J. 1999. Floral structure, development and diversity in Thunbergia (Acanthaceae). Botanical Journal of the Linnean Society 130(1): 1-36. DOI: https://doi.org/10.1006/ bojl.1998.0237

Sierra-Escobar, J. A., R. A. Navarro Alzate and G. J. Yepes. 2017. Efectos de la interacción de hongos micorrizo arbusculares (HMA) y Meloidogyne javanica en plántulas de granadilla (Passiflora ligularis Juss). Revista Bionatura 2: 21-26. DOI: https://doi.org/10.21931/RB/2017.02.03.4

Sieverding, E. 1991. Vesicular-arbuscular mycorrhiza management in tropical agrosystems. Deutsche Gesellschaft fuer Technische Zusammenarbeit GmbH. Eschborn, Germany. Pp. 20-45.

Simpson, M. 2019. Plant systematics. Academic press. London, UK. Pp. 535-547.

Sims, J. 1801. Curtis's botanical magazine, or, flower-garden displayed. Couchman and Fry. London, UK. Pp. 50-146.

Siqueira, J. O. and O. J. Saggin-Júnior. 2001. Dependency on arbuscular mycorrhizal fungi and responsiveness of some Bra- zilian native woody species. Mycorrhiza 11: 245-255. DOI: https://doi.org/10.1007/s005720100129

Thomson, J. D. 2006. Tactics for male reproductive success in plants: Contrasting insights of sex allocation theory and pollen presentation theory. Integrative and Comparative Biology 46(4): 390-397. DOI: https://doi.org/10.1093/icb/icj046

Uribe-Ángel, M. 1885. Geografía general y compendio histórico del estado de Antioquia en Colombia. Imprenta de Victor Goupy y Jourdan. Paris, Francia. Pp. 496-504.

Vaissière, B., B. Freitas and B. Gemmill-Herren. 2011. Protocol to detect and assess pollination deficits in crops: a handbook for its use. Food and Agriculture Organization of the United Nations. Rome, Italy. Pp. 19-28.

Van der Hammen, T. and A. M. Cleef. 1983. Trigonobalanus and the tropical amphi-pacific element in the North Andean Forest. Journal of Biogeography 10(5): 437. DOI: https:// doi.org/10.2307/2844750

Vleeshouwers, L., H. Bouwmeester and C. Karssen. 1995. Redefining seed dormancy: An attempt to integrate physiology and ecology. Journal of Ecology 83(6): 1031-1037. DOI: https:// doi.org/https://doi.org/10.2307/2261184

Wahl, S. and P. Ryser. 2000. Root tissue structure is linked to ecological strategies of grasses. New Phytologist 148(3): 459-471. DOI: https://doi.org/10.1046/j.1469-8137.2000.00775.x

Webb, C. J. and D. G. Lloyd. 1986. The avoidance of interference between the presentation of pollen and stigmas in angiosperms II. herkogamy. New Zealand Journal of Botany 24(1): 163-178. DOI: https://doi.org/10.1080/0028825X.1986.10409726

Westerkamp, C. and R. Claßen-Bockhoff. 2007. Bilabiate flowers: The ultimate response to bees? Annals of Botany 100(2): 361-374. DOI: https://doi.org/10.1093/aob/mcm123 